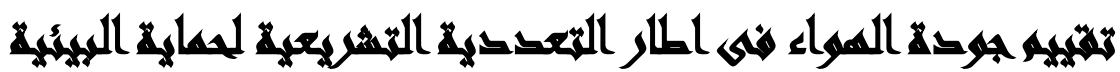

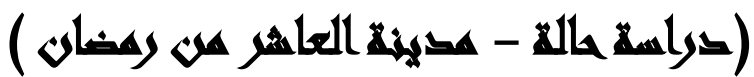

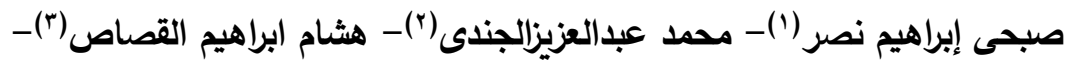

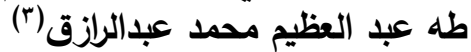

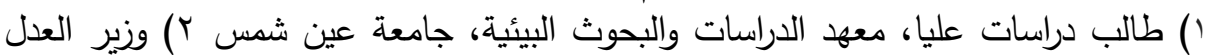

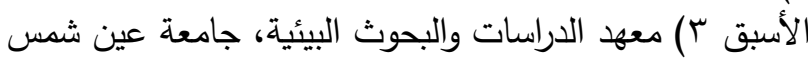

\section{المستيلتص}

قمنا من خلال هذا البحث بقياس أهم ملوثات الهواء ومنها الجسيمات العالقة من خلال

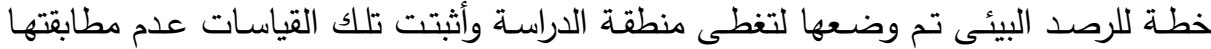

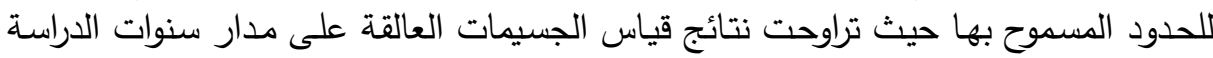

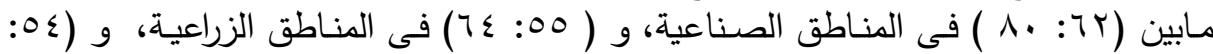

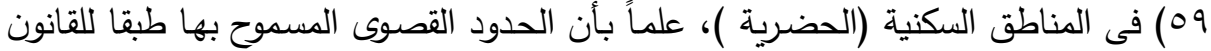

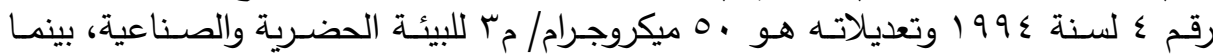

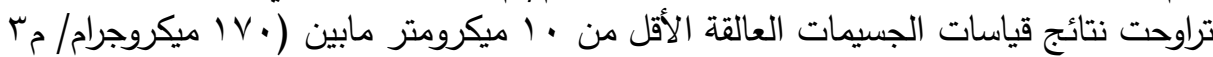

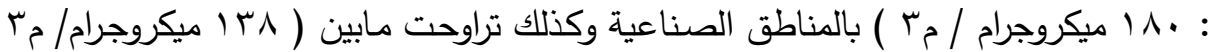

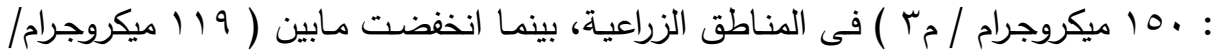

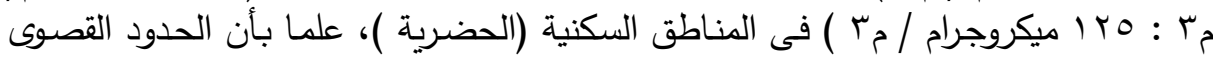

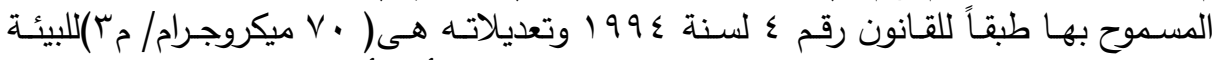

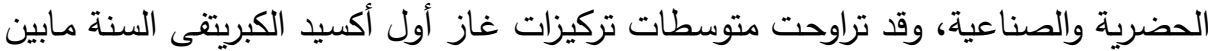

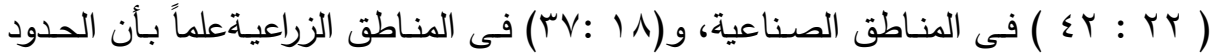

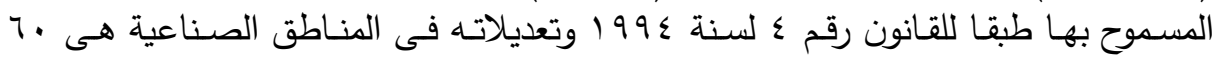

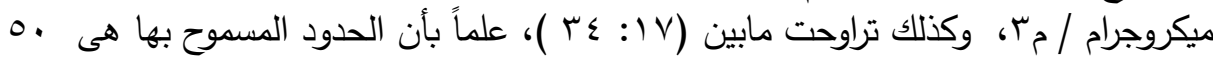

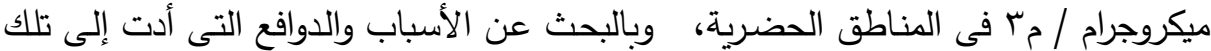

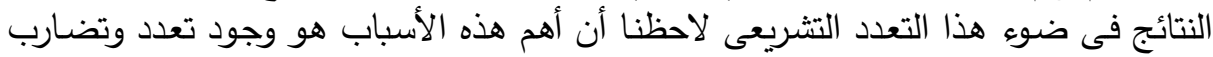

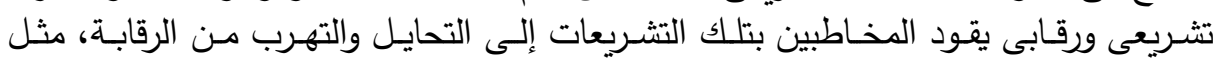

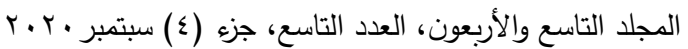

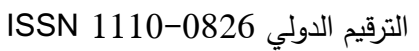




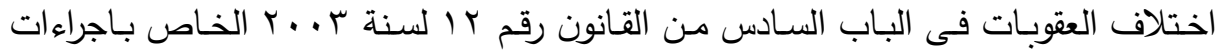

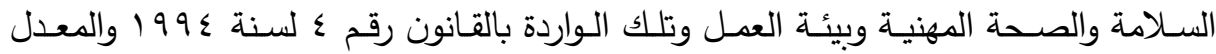

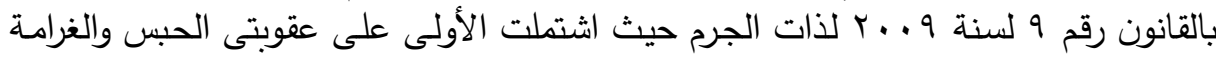

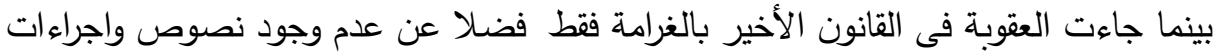

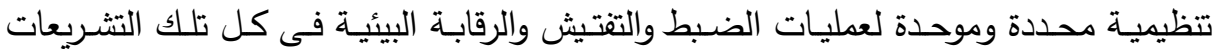

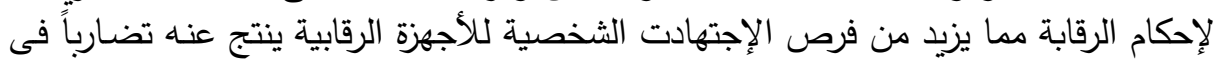

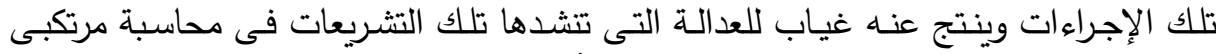

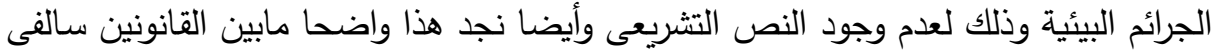

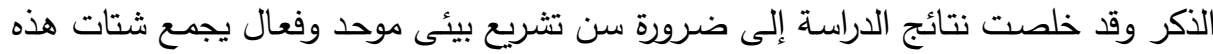
القواعد القانونية ويصهرها فى بوتقة واحدة تكون شاملة لكل القوانين التى تعنى بالبيئة المفتوحة

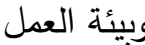
الكلمـات الدالـة: جودة الهواء بمدينـة العاشر من رمضـان - تعدد التشريع البيئي - تعارض التشريع البيئي

\section{xantll}

عرّف المشرع المصرى تلوث الهواء فى المادة الأولى من القانون رقم ع لسنة ـ 199

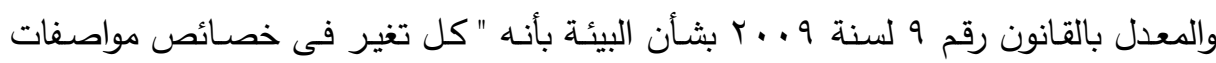

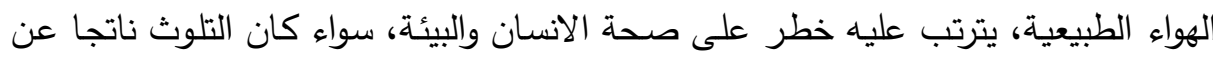

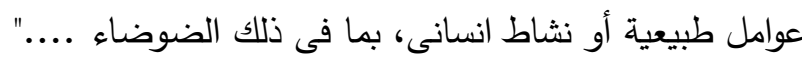
وينتج التلوث الهوائى من مصسادر متعددة ومختلفة ولعل من أهمها الانبعاثات الناتجـة أنساء عن احتراق الوقود، وخاصـة الفحم والبترول، والتى تتشأ بسبب الألات التى تعمل بمحركات التهات

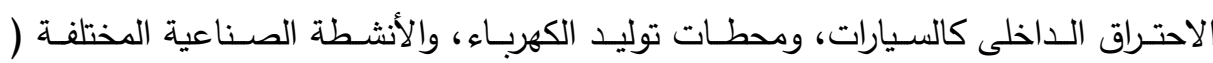

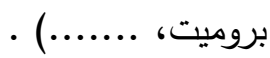

لذلك يمكن التأكيد في هذا المجال على أن أغلب العوامل المسببة لتلوث الهواء هـى

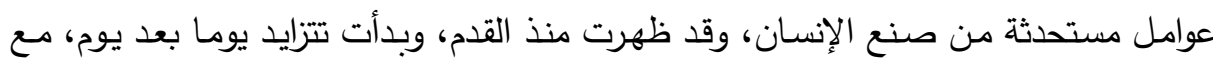


زيادة التقدم العلمى للإنسان ونتيجة أخذه بالأساليب الصناعية والتكنولوجية الحديثة، وظل أثر

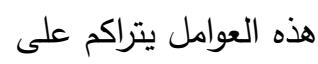
مـر السنين، دون أن يلحظـهـ أحـد حتى ظهـر واضــــا فـى النصـف الثانى مـن القرن العشرين، حين شـعر الانسـان بخطرهـا على حياته، وفطن إلى نتائجها المدمرة فـى البيئة

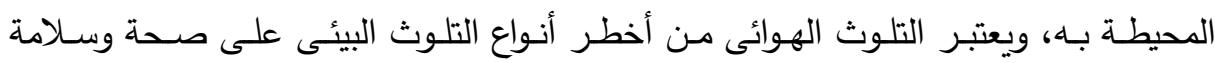

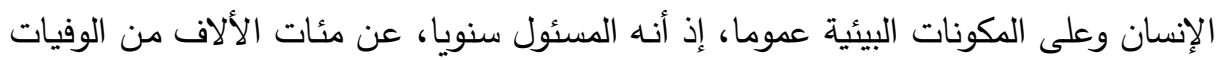
وعن ملايين من الحالات المرضية، وتآكل الكثير من المبانى والمنثأت الأثرية وغير ذلك من الكاته الأضرار المختلفة (فراتش، من ال.....) . وفى جمهوريـة مصر العربية، بلغت هذه الأضرار حجما ليس بالقليل، مما يهدد البيئة

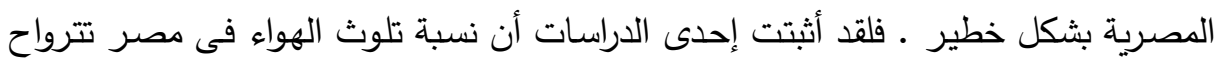
بين (Vو • () أضعاف الحد الأقصى المسموح به فى المناطق السكنية، وأن تزايد نسبة ملوثات الدخان وثانى أكسيد الكبريت فى طبقات الهواء السفلى، قد أصبح ضـاراً بصحة الإنسان

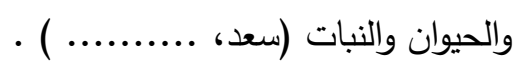

وانطلاقا من القناعة الدولية التى ترسخت لدى كافة الدول والثعوب أن قضية الحفاظ على البيئة لم تعد دربا من دروب الرفاهية، وأنها ضرورة لاستمرارية الحياة، ولما كانت الموارد

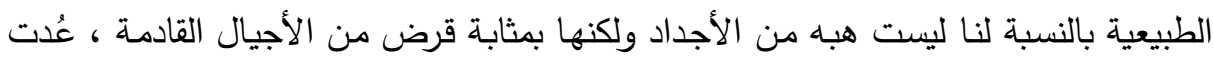

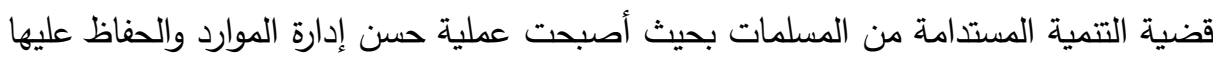
للأجيال القادمة من الحقوق والالتزامات التى تقع على عاتق الثعوب والحكومات، ولقد ظهر التهر

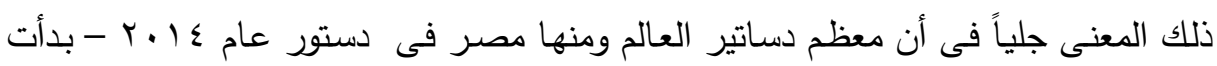
تقدر الحق فى بيئة نظيفة ضمن نصوصها حتى غدا الحق فى بيئة سليمة ونظيفة وأمنه من فن فئن

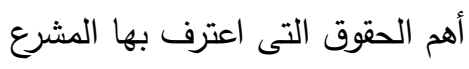

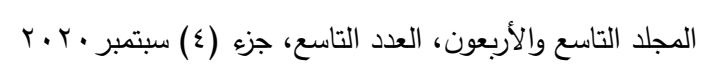

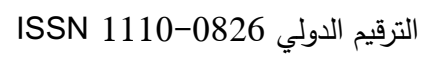


للإنسان، وبالنظر إلى التتظيم القانونى لحماية البيئة فى مصر، نجد عدداً لاحصر لله من القواعد المنظمة والهادفة إلى حماية البيئة، بطريقة مباشرة أوغير مباشرة وعلى الرغم من لن لهن ذلك نجد البيئة فى مصر ، تزداد تدهوراً وتلوثاً، والإنسان محاط بالتلوث، والخطر البيئى يهدده فى كل

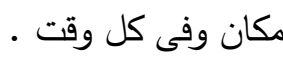
وهذا يشير إلى عدم فاعلية أو عدم جدية القواعد المنظمة لحماية البيئة، ولذلك لابد من

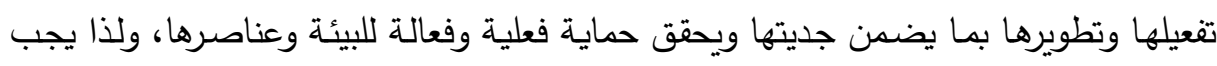

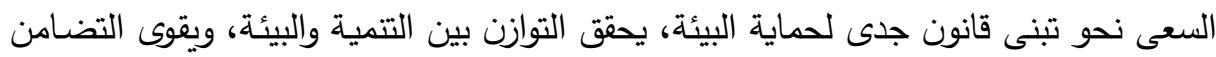

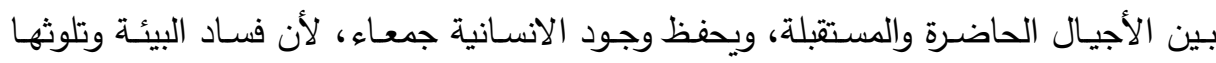
وتدهورها يعد خطراً

يهدد الحياة الصحية الآمنة فى الدولة، بل ويهدد وجود الدولة ذاتها ولذلك فإن بقاء الدولة

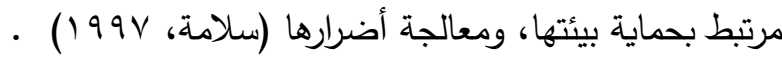

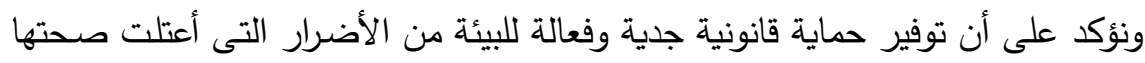

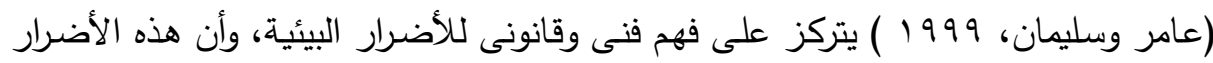

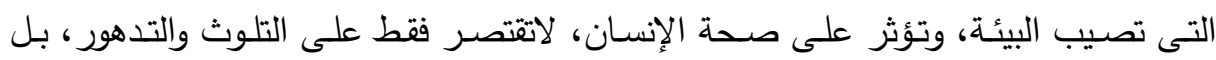
تتعدى ذلك، ومن ثم نستطيع حصر المتسبب فى هذه الأضرار البيئية، وتحديد أسبابها ووضع لصع

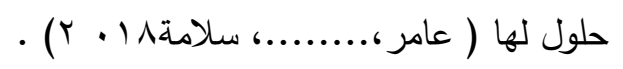
ويهدف هذا البحث إلى تقييم جودة الهواء فى منطقة مدينة العاشر من رمضـان - بسبب

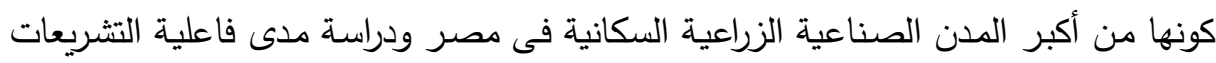
البيئية المتعددة الصادرة فى مصر بشأن حماية البيئة الصناعية والزراعية، وتأثيرها على جودة الهواء وتحقيق الردع المطلوب لحماية البيئة، وتقديم التوصيات المناسبة فى هذا الثأن. 


$$
\begin{aligned}
& \text { مجلة العلوم البيئية } \\
& \text { معهد الدراسات والبحوث البيئية - جامعة عين شمس له } \\
& \text { صبحى إبراهيم نصر وآخرون }
\end{aligned}
$$

الطرق والمهواد Materials and Methods: تم اختيار مدينة العاشر من رمضـان كدراسة حالة - لتقييم جودة الهواء بها فى إطار نظم التشريعية البيئية فى مصر ، ونظرا لكونها

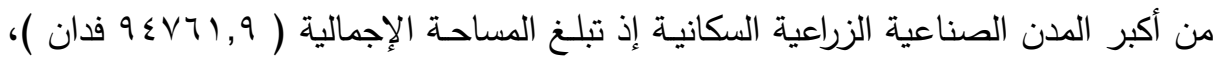
فهى تضم ثلاثة مناطق صناعية هى ( C - B - A بكل منطقة العديد من الصناعات المختلفة من حيث طبيعة الانشطة ومن حيث الآثار البيئية المتوقعة عن هذه الأنثطة، حيث

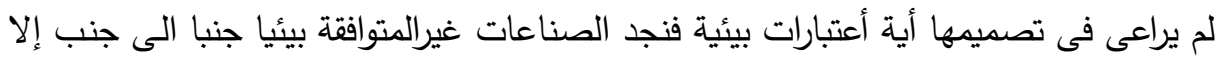

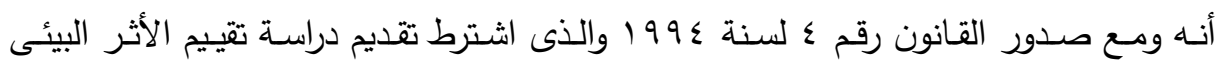
للمشروعات الجديدة قبل البدء فى التتفيذ فقد تم الحد من هذه الظاهره، ناهيك عن أنه تتخلل

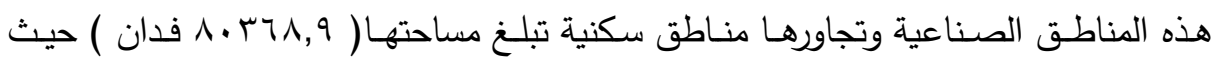
يقطن بها قرابة المليون نسمة، وتقع مدينة العاشر من رمضـان على بعد 00 كم من القاهرة

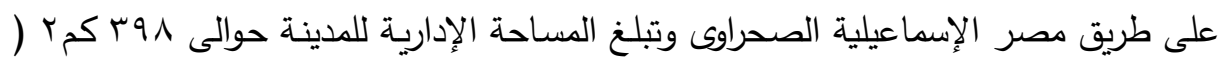
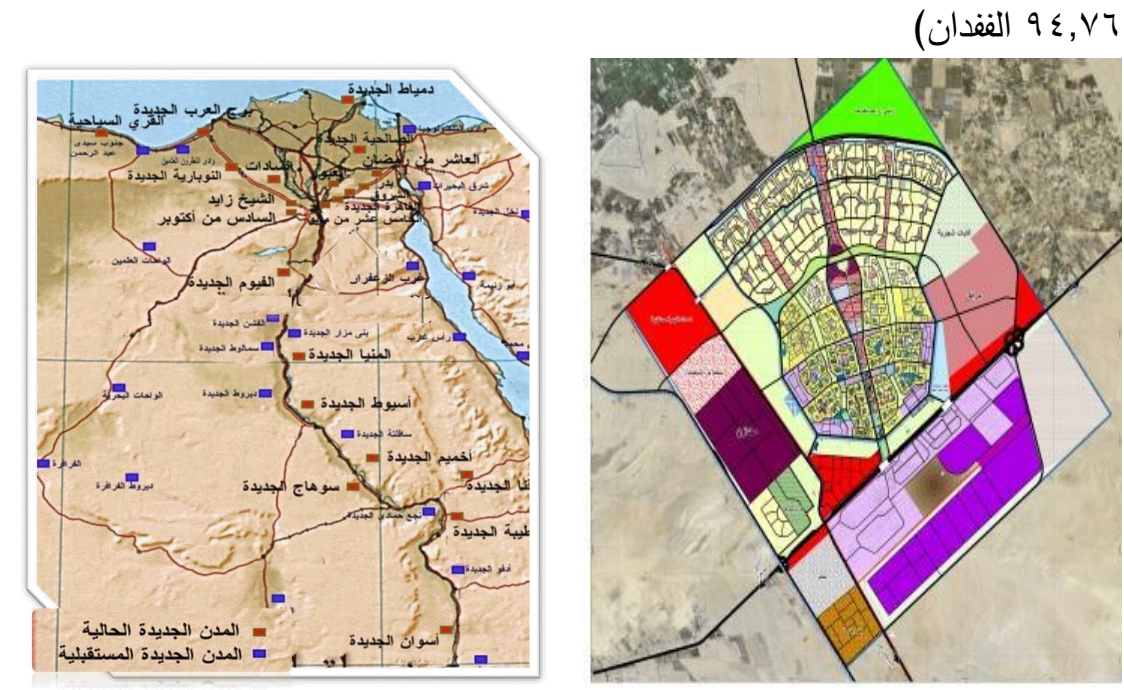

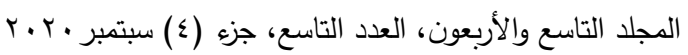

$$
\begin{aligned}
& \text { الترقيم الدولي 0826-1110 }
\end{aligned}
$$




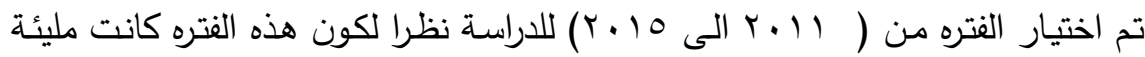
بالإنفلات الرقابى والإضطراب الأمنى والذى نتج عنه إضطراب الذه معدلات الأداء لأجهزة الدولة

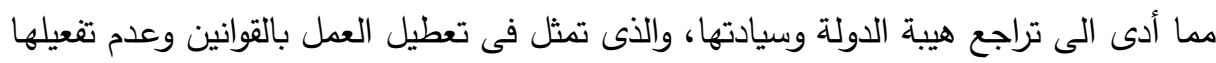

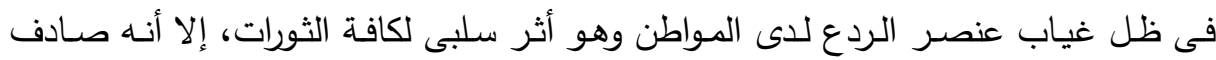

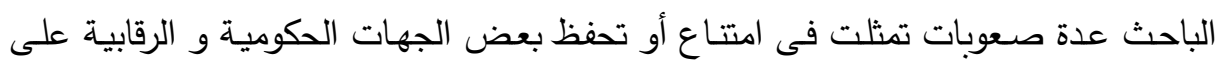

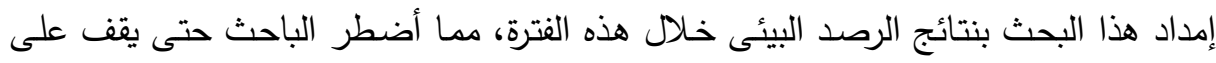

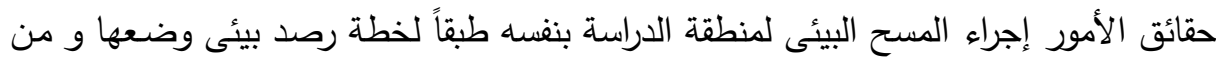

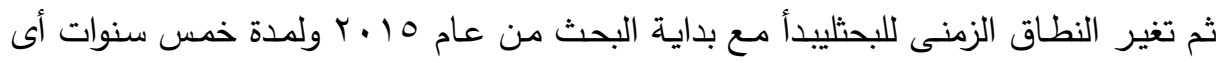
ينتهى فى عام 9 1 ـ ب بالإضافة إلى ما هو منشور بالتقارير الدورية لجهاز شئون البيئة. تم تقسيم مدينة العاشر من رمضان إلى المنطقة الصناعية، والمنطقة الزراعية، والمنطقة

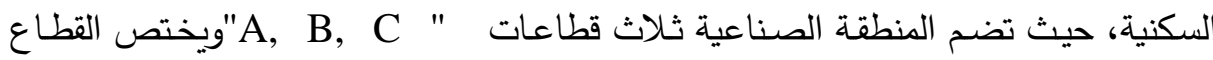
الصناعى (A) بالصناعات الثقيلة، ويختص القطاع الصناعى (B) بالصناعات المتوسطة، ويختص القطاع الصناعى ( C) بالصناعات الصغيرة والمتتاهية الصغر ، كما تضم المنطقة الزراعية ثلاثة قطاعات هى " "A, B, C حيث يختص القطاع الزراعى (A) بالحوش الزراعية أو المزارع، وتضم المنطقة السكنية به حى سكنى بكثافة سكانية تفوق المليون 


$$
\begin{aligned}
& \text { مجلة العلوم البيئية } \\
& \text { معهد الدراسات والبحوث البيئية - جامعة عين شمس له } \\
& \text { صبحى إبراهيم نصر وآخرون }
\end{aligned}
$$

\begin{tabular}{|c|c|c|c|c|c|}
\hline \multicolumn{4}{|c|}{ 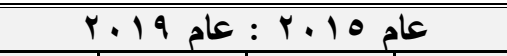 } & \multirow[b]{2}{*}{ الملوثات الهوائية } & \multirow[b]{2}{*}{ b } \\
\hline الرابيع & الثالثيع & الثانيى & الألرلّ & & \\
\hline & & & & الجسيمات الصلبة العالقة pm2.5 & 1 \\
\hline & & & & الجسيمات الصلبة العالقةPm10 & $r$ \\
\hline & & & & ثانى أكسيد الكبربت & $r$ \\
\hline & & & & ثاني أكسيد النيتروجين & $\varepsilon$ \\
\hline & & & & غاز أول أَكسيد الكربون & 0 \\
\hline & & & & الرصاص صلر & 7 \\
\hline
\end{tabular}

تم وضع خطة الرصد البيئى لملوثات الهواء بتلك المناطق على النحو التالى :توقيتات الرصد البيئى:-

يتم تكرار هذه الخطة على مدار الأربع سنوات القادمة وصولا لعام 9 ـ ب . .

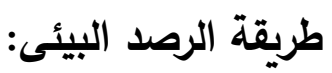

$$
\text { تم أخذ عينات الهواء باستخدم الأجهزة الأتية :- }
$$

- ساحب عينات الاتربة بحجم كبير (High Volume Sampler) لقياس الأتربة العالقة

$$
\text { الكلية (Total suspended Particulates) }
$$

- ساحب العينات الثخصى (Personal sampler) لقياس الأتربة القابلة للاستنشاق (Respirable Particulates )

- جهاز الامتصاص الذرى (Atomic Absorption Spectrophotometer) لقياس الفلزات الثقيلة (الرصاص)

طرق القياس: تم استخدام طرق طبقا للطرق القياسية المستخدم لقياس تلوث الهواء

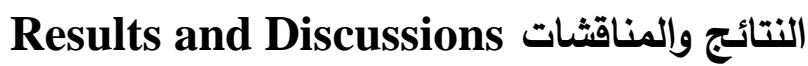

• نتائج رصد ملوثات الهواء: الحدود القصوى المسموح بها قانوناً لمتوسطات تركيزات

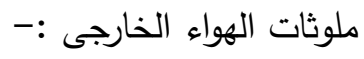

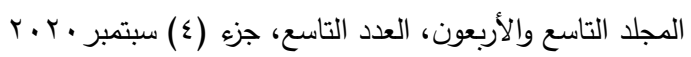

$$
\begin{aligned}
& \text { الترقيم الدولي 0826-1110 }
\end{aligned}
$$


طبقاً للملحق رقم ( 0 ) من اللائحة التتفيذية للقانون رقم ( ع ) لسنة ـ 199 و المعدل

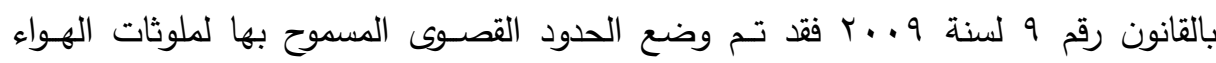

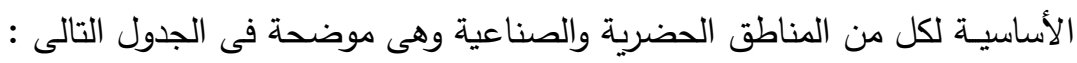
جدول رقم(1): الحدود القصوى لملوثات الهواء

\begin{tabular}{|c|c|c|c|c|c|c|}
\hline \multicolumn{4}{|c|}{ الحد الآصى للتركيز ( ميكروجرام / مج ) ) } & \multirow[t]{2}{*}{ المنطقة } & \multirow[t]{2}{*}{ الملــوثات } & \multirow[t]{2}{*}{ p } \\
\hline سنة & يوم & ^ ساعة & ساعة & & & \\
\hline 0. & 140 & - & r... & حضربة & \multirow{2}{*}{ ثانى أكسيد الكبريت } & \multirow[b]{2}{*}{1} \\
\hline 7. & 10. & - & ro. & صناعية & & \\
\hline 7. & 10. & - & $r \ldots$ & حضربة & \multirow{2}{*}{ ثانى أكسيد النيتروجين } & \multirow{2}{*}{ r } \\
\hline 入. & 10. & - & $r \ldots$ & صناعية & & \\
\hline - & - & 1. & $\mu$. & حضربة & \multirow{2}{*}{ 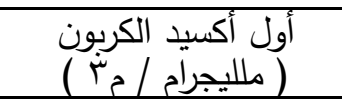 } & \multirow{2}{*}{$r$} \\
\hline - & - & 1. & $r$. & صناعية & & \\
\hline$\cdot, 0$ & - & - & - & حضربة & \multirow{2}{*}{ الرصاص } & \multirow[b]{2}{*}{$\varepsilon$} \\
\hline $1, \cdot$ & - & - & - & صناعية & & \\
\hline$V \cdot$ & 10. & - & - & حضربة & \multirow{2}{*}{ أقل منيمات الصلبة العالقة } & \multirow{2}{*}{0} \\
\hline$V$. & 10. & - & - & صناعية & & \\
\hline 0. & A. & - & - & حضربة & \multirow{2}{*}{ أقل من الجيمات الصلبة العالقة } & \multirow{2}{*}{7} \\
\hline 0. & A. & - & - & صناعية & & \\
\hline - & - & Tr. & 11. & حضربة & \multirow{2}{*}{ الأوزون } & \multirow{2}{*}{ V } \\
\hline - & - & Ir. & 11. & صناعية & & \\
\hline
\end{tabular}

1. الجسيمات الصلبة العالقة (Particulates Matter)

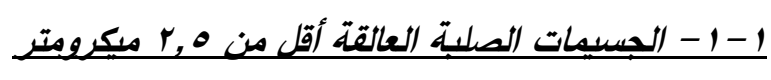

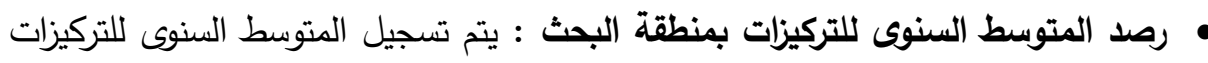

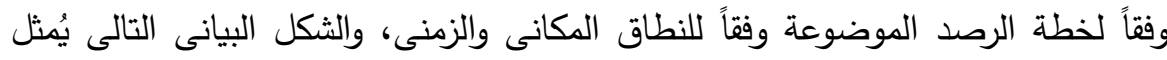

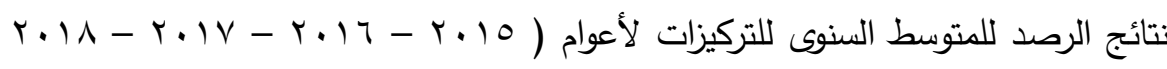
$\cdot(r \cdot 19-$ 


$$
\begin{aligned}
& \text { مجلة العلوم البيئية } \\
& \text { معهد الدراسات والبحوث البيئية - جامعة عين شمس لبنه } \\
& \text { صبحى إبراهيم نصر وآخرون }
\end{aligned}
$$

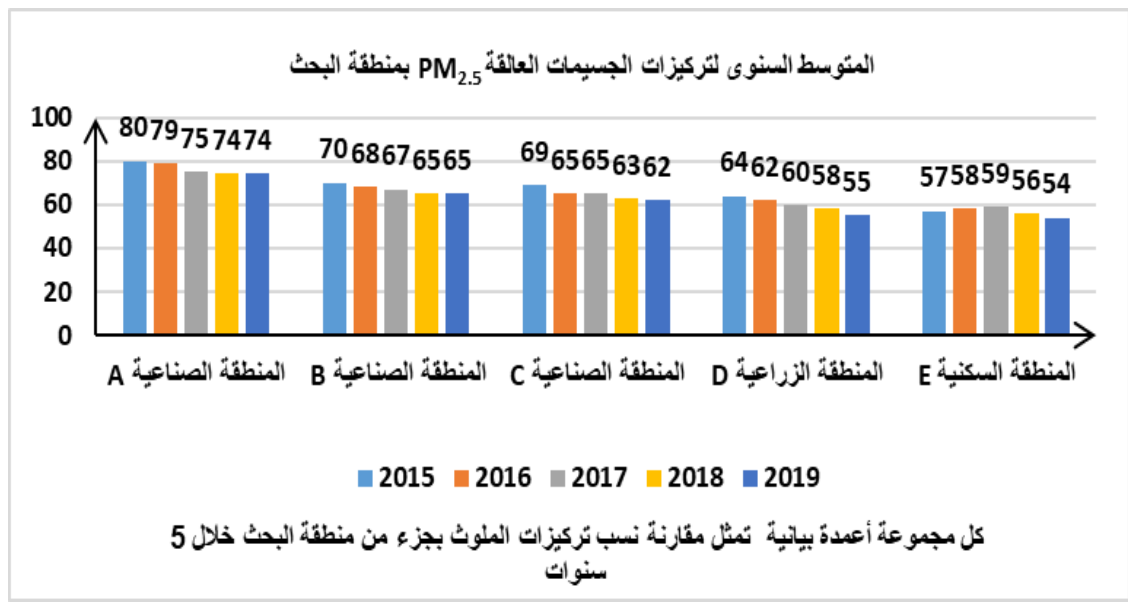

ب - - الجسيمات الصلبة العلائقة أقل من ـ ا ميكرومتر

• رصد المتوسط السنوى للتركيزات بمنطقة البحث : يتم تسجيل المتوسط السنوى للتركيزات وفقاً لخطة الرصد الموضوعة وفقاً للنطاق المكانوالزمنى، والثكل البيانى التالى يُمثل نتائج

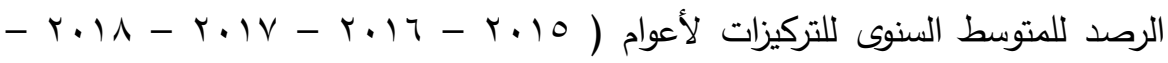

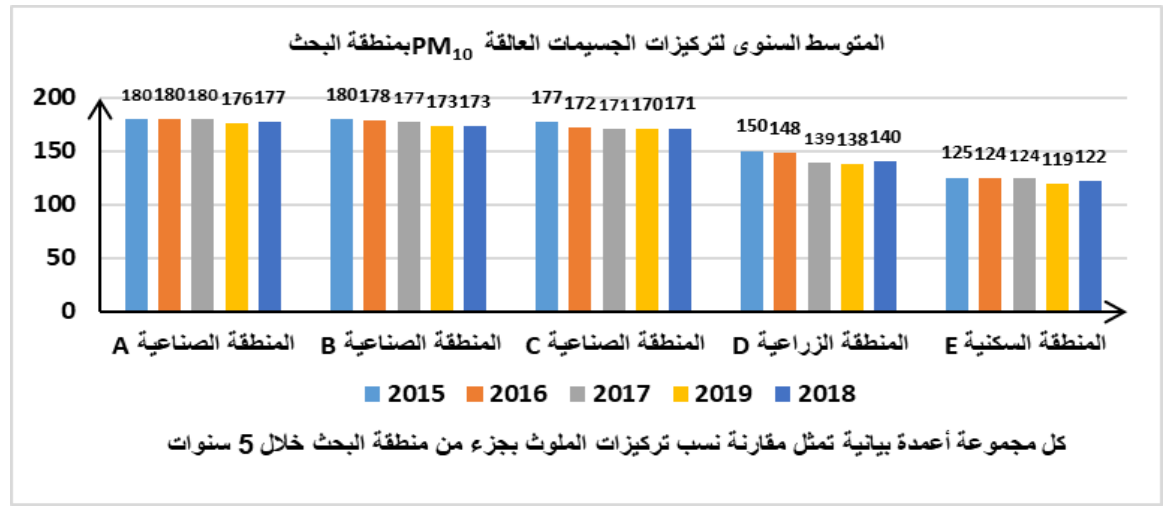

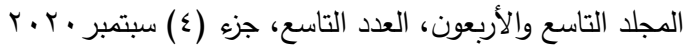

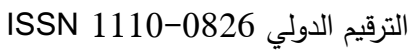


r r از ثانى أكسيد الكيريت • رصد المتوسط السنوى للتركيزات بمنطقة البحث: يتم تسجيل المتوسط السنوى للتركيزات وفقاً لخطة الرصد الموضوعة وفقاً للنطاق المكانى والزمنى، والثكل البيانى التالى يُمثل لئل

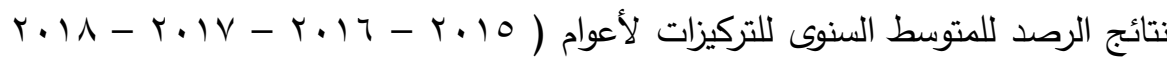
$\cdot(r \cdot 19-$

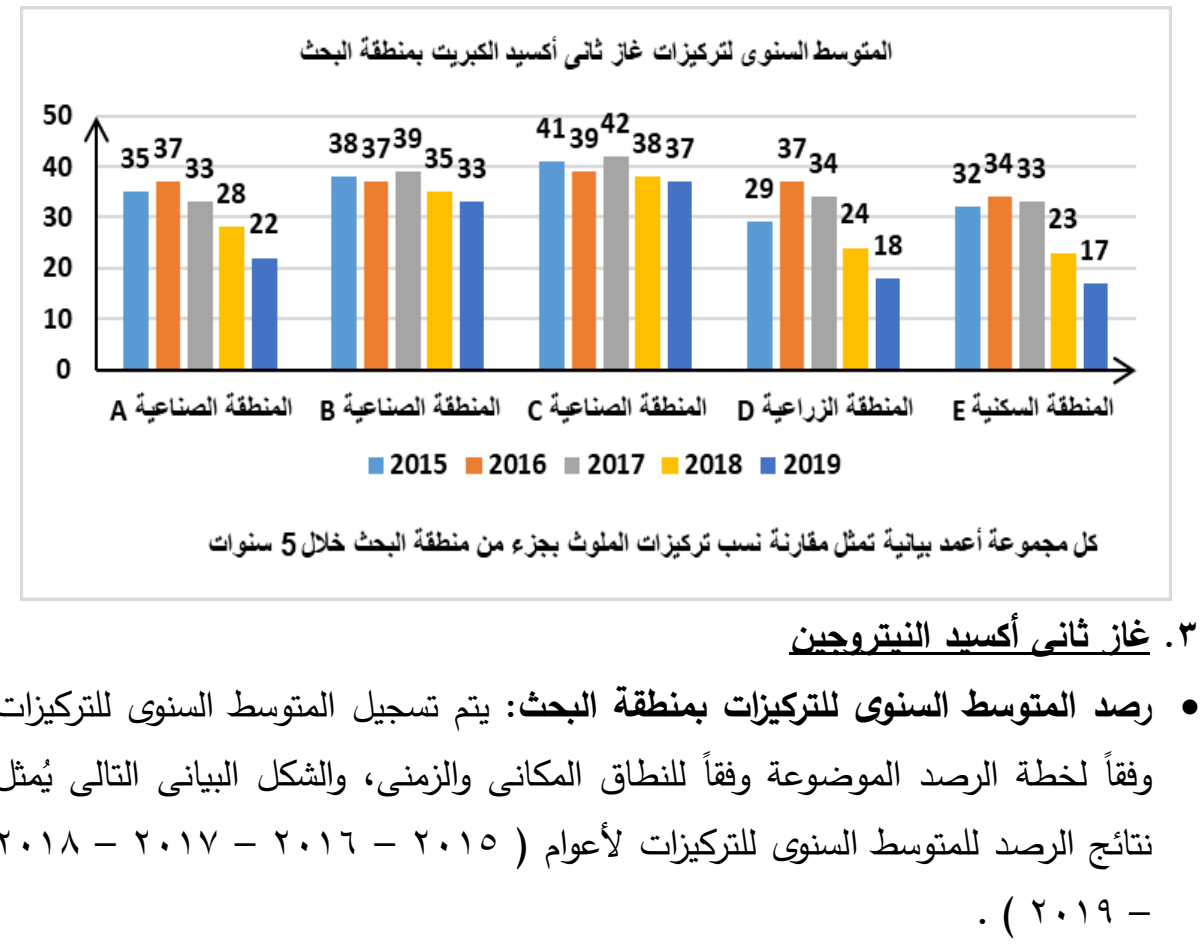


مجلة العلوم البيئية

معهد الدراسات والبحوث البيئية - جامعة عين شمس لئه

صبحى إبراهيم نصر وآخرون

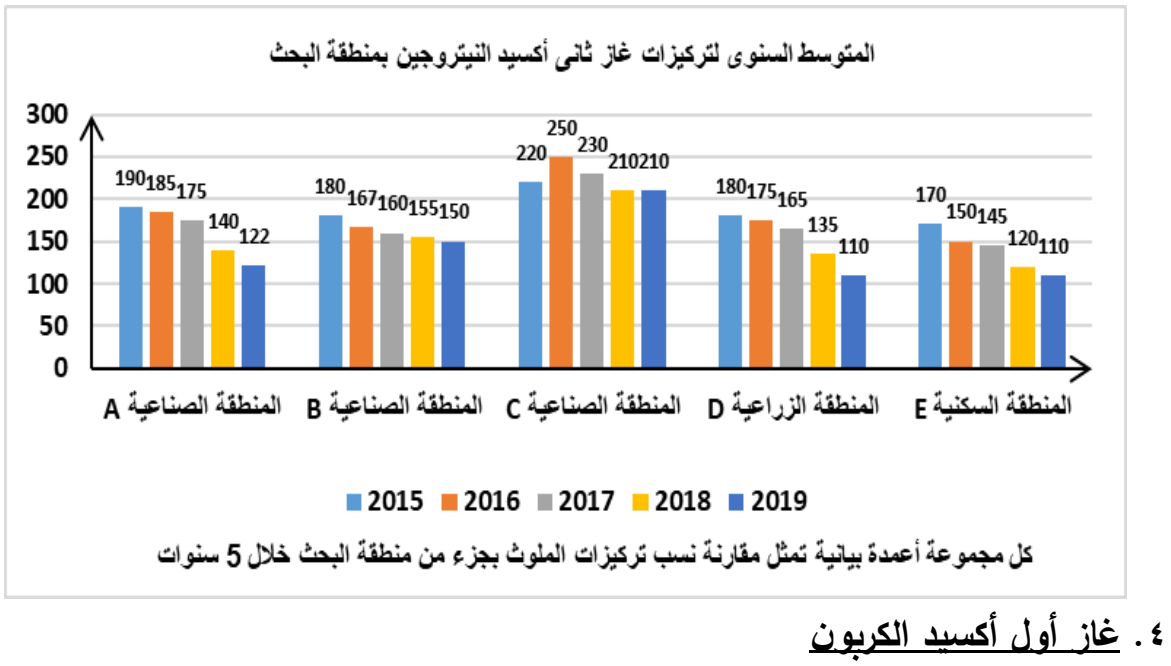

• نتائج متوسط التركيزات لكل ساعة خلال عام بمنطقة البحث: يتم تسجيل نسبة توافق

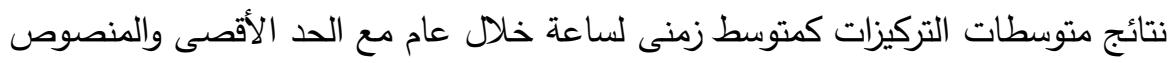

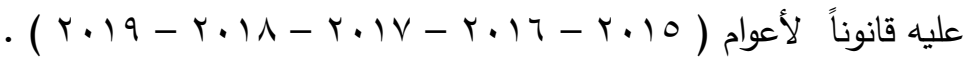$$
\text { المتوسط السنوى لتُركيزات أول أكسبد الكربون بمنطقة البحث }
$$

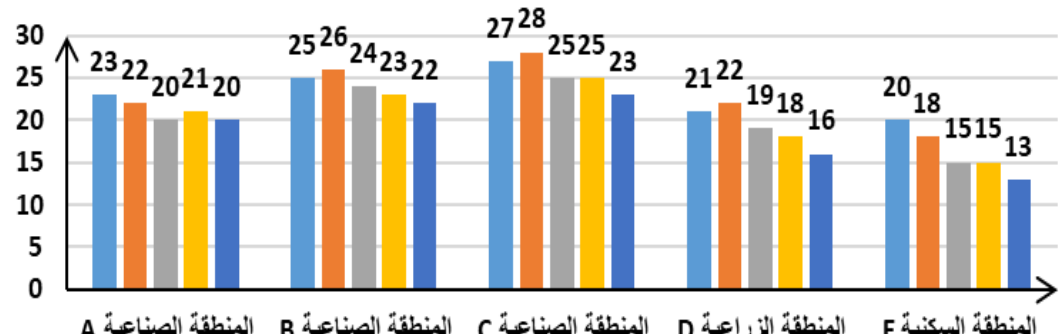

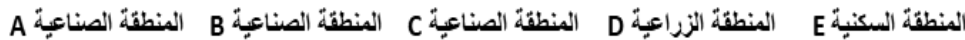

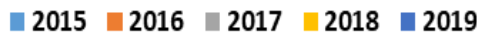

كل مجموعة أعدة بيانبة تمثل مقارنة نسب تركيزات الملوث بجزء من منطقة البحث خلال 5 سنوات

0 - م. الرصاص

المجلد التاسع والأربعون، العدد التاسع، جزء (ع) سبتمبر • r.

الترقيم الدولي 0826-1110 115N 


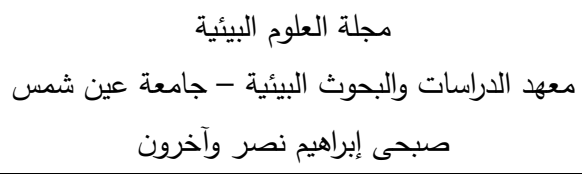

• رصد المتوسط السنوى للتركيزات بمنطقة البحث : يتم تسجيل المتوسط السنوى للتركيزات وفقاً لخطة الرصد الموضوعة وفقاً للنطاق المكانى والزمنى، والثكل البيانى التالى يُمثل

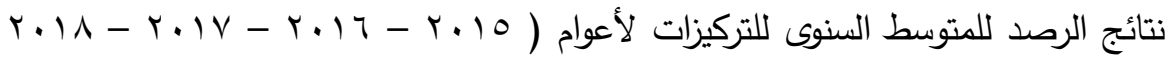
$\cdot(r \cdot 19-$

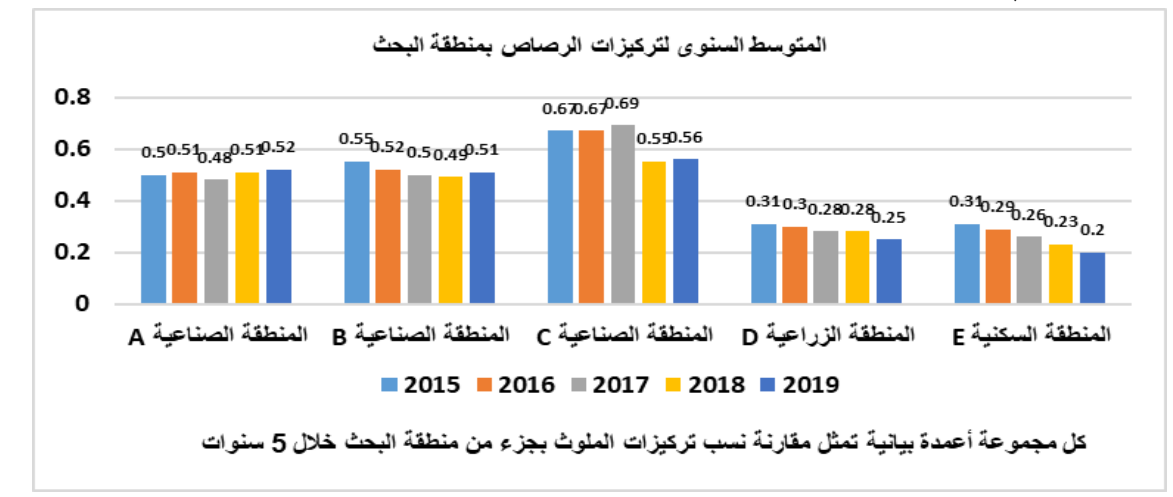

صور حيه استمرارية الانبعاثات الغازية والجسيمات العالقة فى هواء مدينة العاشر من رمضان 
مجلة العلوم البيئية

معهد الدراسات والبحوث البيئية - جامعة عين شمس لئية

صبحى إبراهيم نصر وآخرون

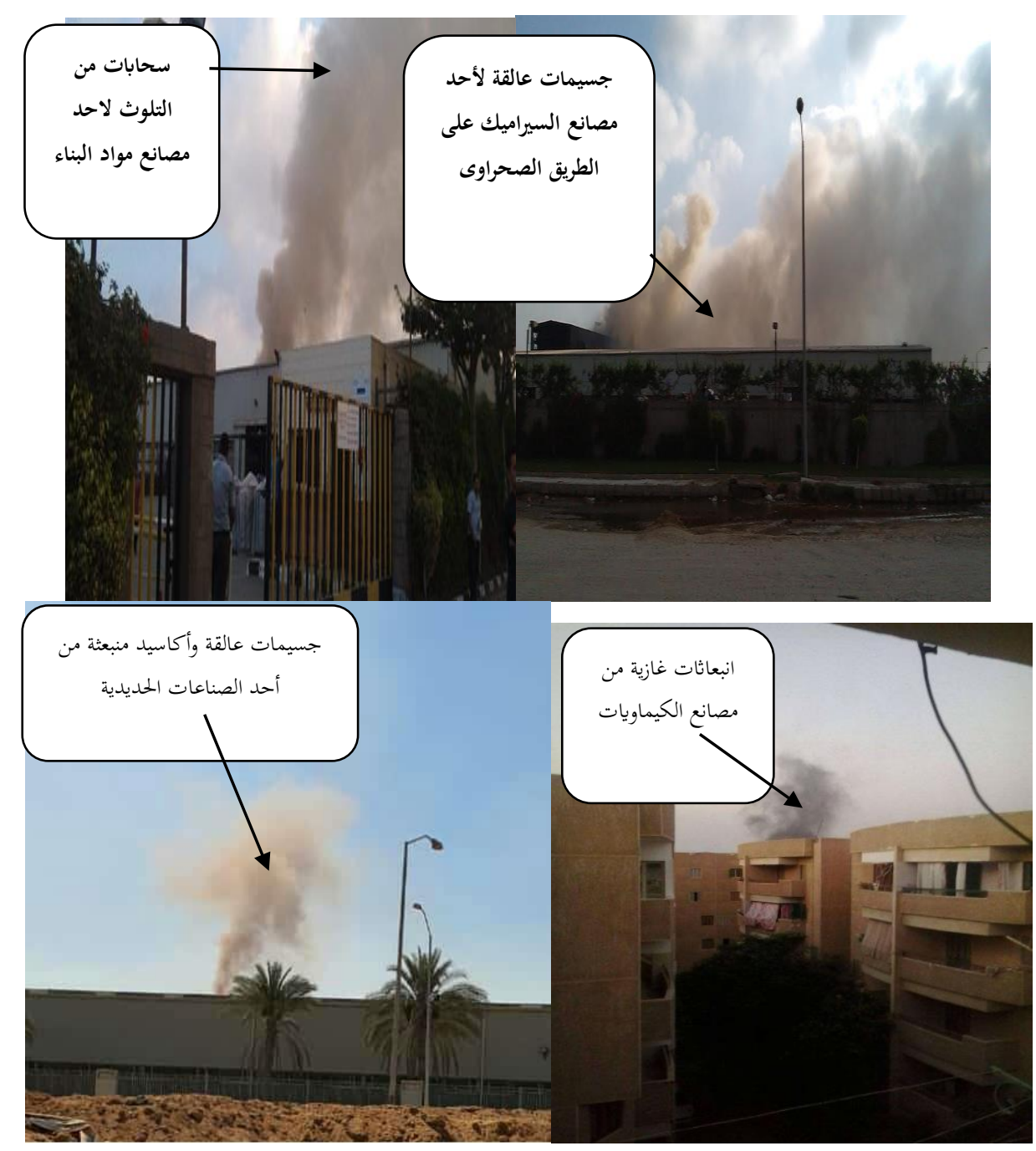

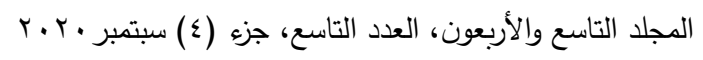

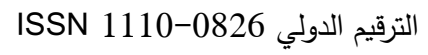


مناقشة نتائج الرصد البيئى لملوثات الهواء وتقييم مدى فاعلية التشريعات البيئية المتعددة

\section{وبتحليل نتائج رصد ملوثات الهواء بمدينة العاشر من رمضان تلاحظ لنا الأتى :-}

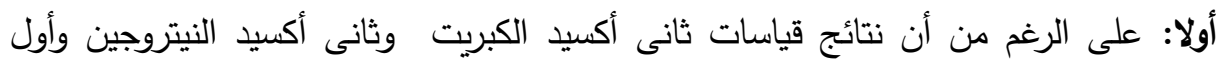
أكسيد الكربون والرصاص أقل من الحدود المسموح بها فى القانون إلا أننا لم نجد تحسناً

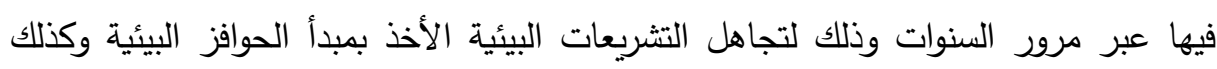
عدم الأخذ بمبدأ الملوث يدفع مما جعل المخاطبين بالقانون مكتفين بأن هذه القياسات داخل

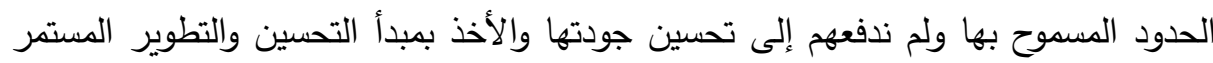

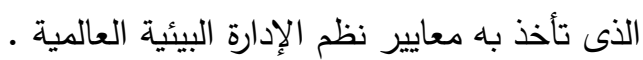

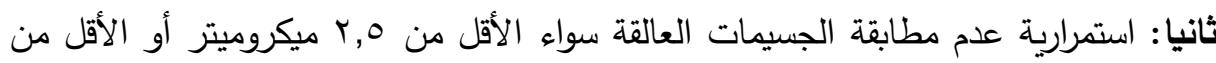

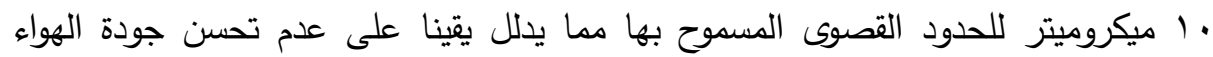

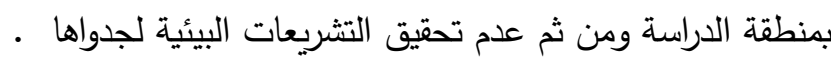

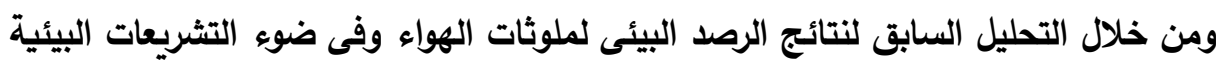
المتعددة نستطيع أن نستخلص الأسباب والدوافع التى أدت إلى هذه النتائج وهى :(1) عدم جدوى القواعد المنظمة لحماية البيئة بثكل عام والبيئة الهوائية - محل الدراسة بشكل خاص - نظرا للتعدد و التشتت بل و التضارب - أحيانا - لتلك القواعد القانونية

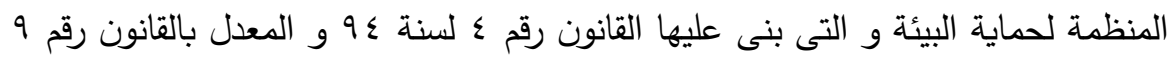

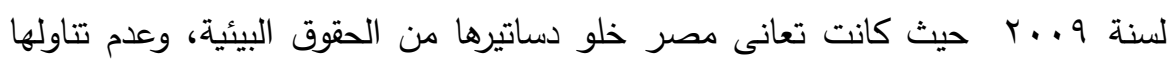
لقضايا البيئة بثكل حقيقى وملموس، وذلك حتى تم إضافة المادة رقم 09 من تعديل الدستور فى V. . . P م، وجاءت ضعيفة للغاية، ولاتؤكد رعاية الدولة الحقوق البيئية

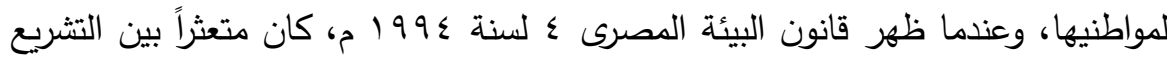

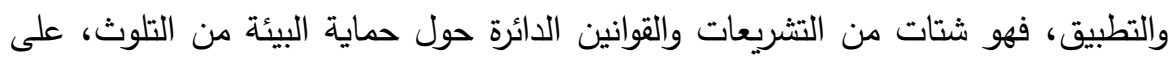


صورة تعانى من عدم الدقة فى الصياغة وسوء اختيار التقنية القانونية وأحيانا عدم سلامة

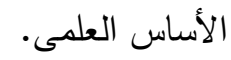

ويرى الباحث أن أهم مايجعل القواعد المنظمة لحماية البيئة فى مصر غير ذى جدوى ولاتؤتى بثمارها ولاتحقق الردع المطلوب لوقف التعدى الصارخ على البيئة سواء كان تعديا

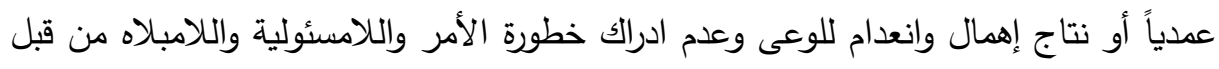

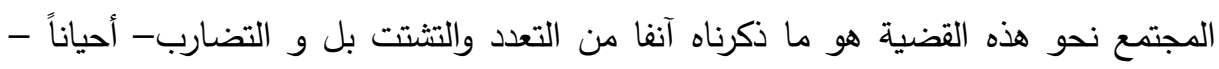

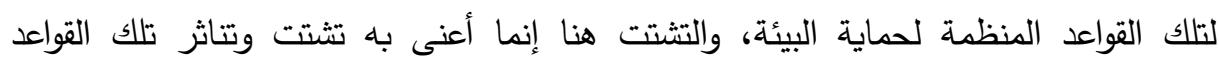
الحمائية فى العديد من القوانين والتشريعات والتى يترتب عليها تعدد فى الجهات القائمة على لئه

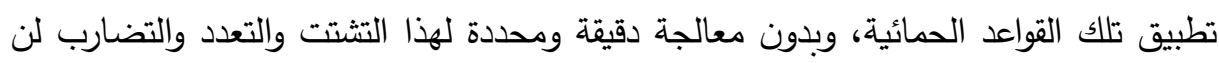
يتحقق الردع المطلوب ولن تصبح هذه القواعد المنظمة قواعد حمائية فى يوم ما، على الرغم

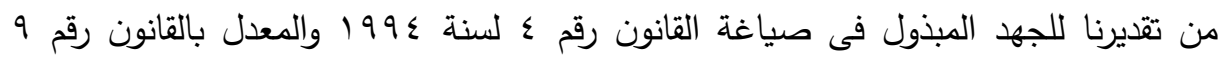

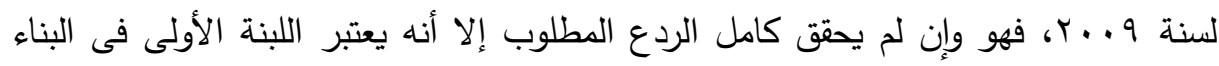

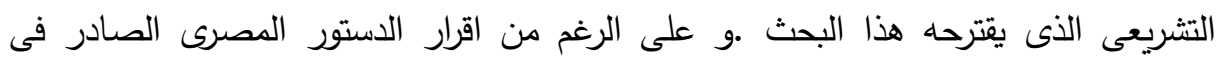

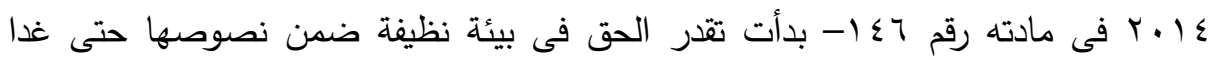
الحق فى بيئة سليمة ونظيفة وأمنه من أهم الحقوق التى اعترف بها المشرع للإنسان، وبالنظر فئه

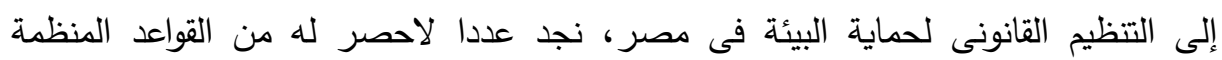

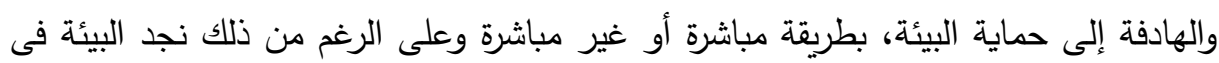

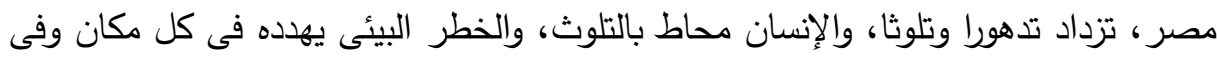

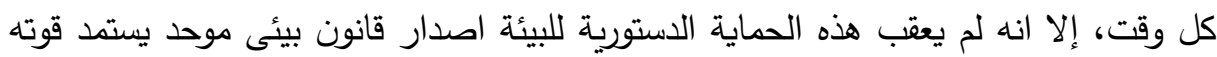
من تلك الحماية الدستورية و يجمع و بحق هذا الثتات التشريعى فى قالب واحد و يتضمن لهن تصحيحا لكل السلبيات و العوار الذى لحق ببعض ومواده كما سنوضح فى هذا البحث الا ان

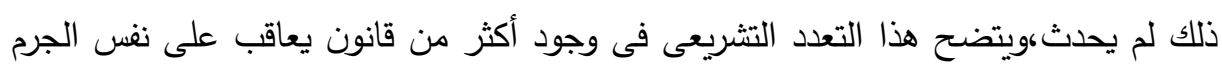

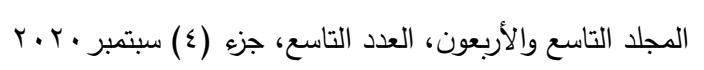


البيئى عن طريق أكثر من وزارة مما يعد تعدداً فى التشريع وتعدداً فى التطبيق مثل ماورد

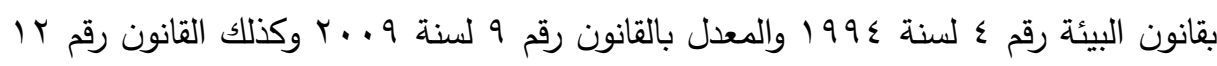

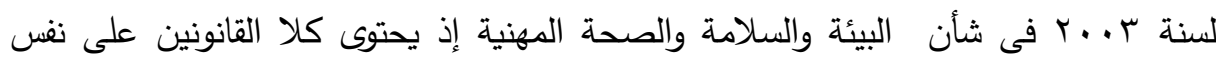
الحدود القصوى المسموح بها ويطبق هذين القانونين وزارتين هما وزارة الدولة لشئون البيئة ممثلة فى جهاز شئون البيئة وفروعة بالأقاليم وكذلك إدارات شئون البيئة بالمحافظات وأجهزة

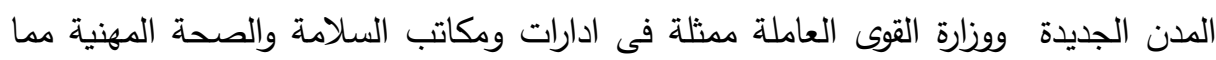
يعتبر تعدداً فى الجهات الرقابية فضلا عن وجود تعارض فى آليات التقتيش على النحو التالى

أولا: تعدد الجهات الرقابية المعنية بتطبيق قانون واحد داخل الوزارة الواحدة مابين مركز رئيسى

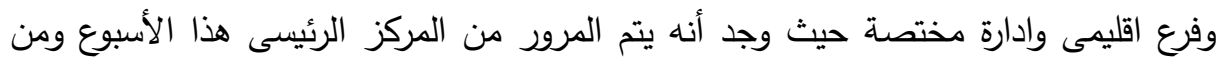

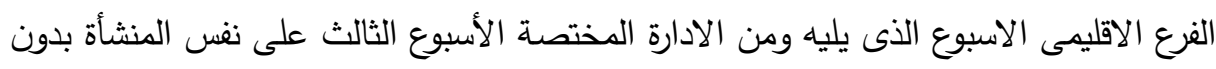

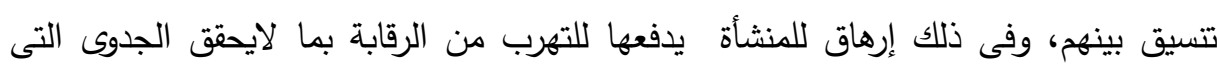
ينشدها القانون ثانيا: تعدد الجهات الرقابية المعنية بتطبيق كل قانون من هذين القانونين مثل المعنيين بتطبيق

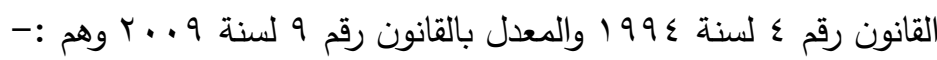
() ممثلو جهاز شئون البيئة وفروعه

r) مديرى ومفتشى ادارات شئون البيئة بمكاتب شئون البيئة بالمحافظات والمراكز والأحياء

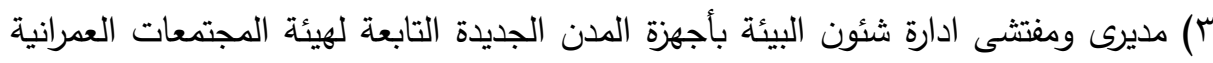
الجديدة

ع) مديرى ومفتشى ادارة شئون البيئة بالجمارك والموانى والمنطقة الأقتصادية بالسويس

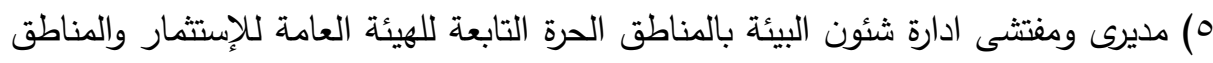

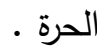


وكذلك المعنيين بتطبيق القانون رقم r ا لسنة r . . ب وتعديلاته وهم :-

ا-مديرى ومفتشى ادارة السلامة والصحة المهنية بوزارة القوى العاملة ץ-مديرى ومفتشى ادارة السلامة والصحة المهنية بوزارة القوى العاملة بمديريات القوى العاملة بالمحافظات r-مديرى ومفتشى مكاتب السلامة والصحة المهنية بوزارة القوى العاملة بالمراكز والأحياء والمدن الجديدة

ع-مديرى ومفتشى السلامة والصحة المهنية بالمنافذ (جمارك وموانى ) ولقد وجدنا أن هذا الكم من الجهات الرقابية تراقب نفس الجرم مما يؤدى إلى تسارع

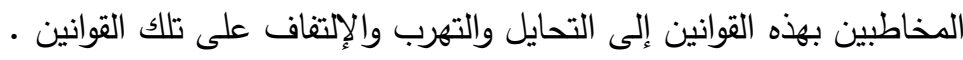
ثالثا: اختلاف بل وتعارض آليات وإجراءات الضبط والتنتيش والرقابة من قبل الجهات المعنية بتطبيق تلك القوانين والتشريعات البيئية المختلفة على النحو التالى :-

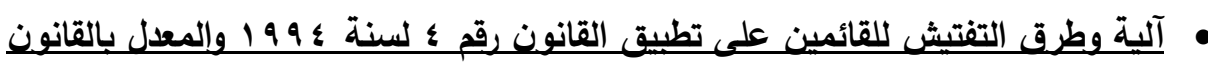

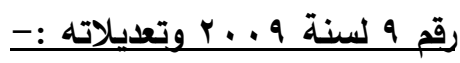
1-حضور لجنة فنية مشكلة من مفتشى أجزة البيئة السابق ذكرها للمرور على المنشأة سواء

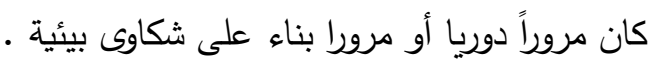

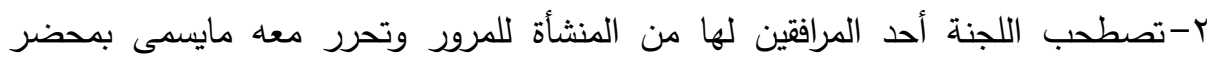

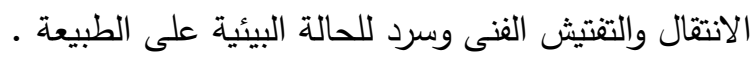

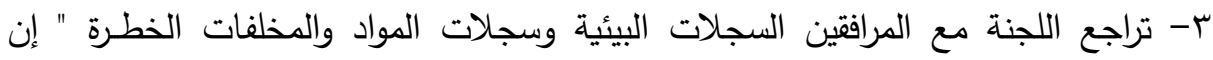

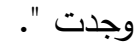
ع - تقوم اللجنة بعمل العينات البيئية لمطابقة الحدود القصوى المسموح بها فى القانون .

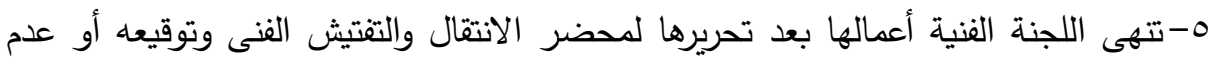
توقيعه " فى حالة رفض التوقيع " من قبل مرافق اللجنة .

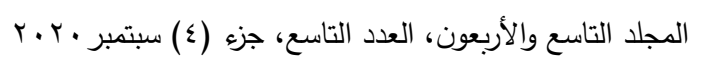


7-تعود اللجنة الفنية لمقر عملها سواء كان أحد فروع جهاز شئون البيئة أو المركز الرئيسى

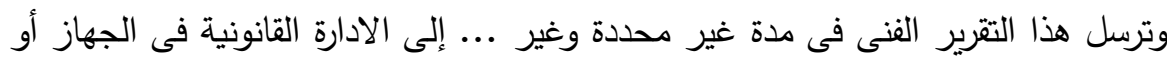
• الفرع

V- ليتولى محام من هذه الإدارة مراجعة ماورد بالتقرير الفنى ومطابقته بمواد القانون ليقوم بدوره

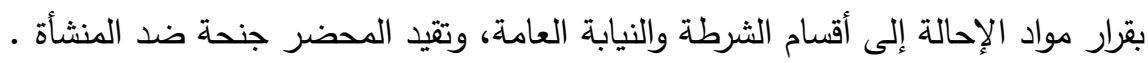

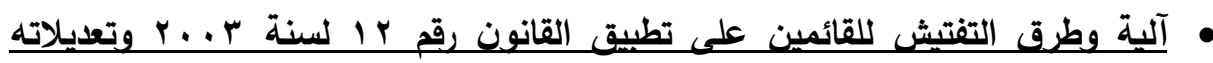
والتلائحة ( الكتاب الخامس والسادس ) الخاص بالسلامة والصحة المهنية :-1-حضور لجنة فنية مشكلة من مفتشى السلامة والصحة المهنية السابق ذكرهم للمرور على المنشأة سواء كان مرورا دوريا أو مروراً بناء على شكاوى بيئية

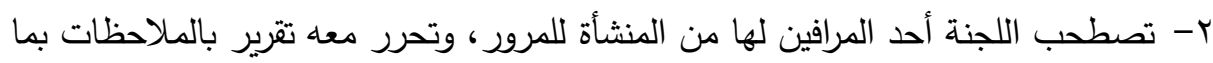
رأته وذلك بعد مراجعة السجلات اللازمة r-تقوم اللجنة بعمل عينات بيئية للوقوف على مدى مطابقة الحدود القصوى الواردة بالقانون

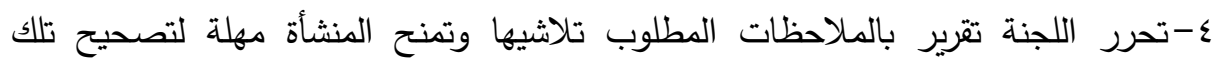
الملاحظات أو المخالفات فى خلال شهر من تاريخ التفتيش وفى حالة عدم تصحيح تلك ولك المخالفات فى خلال المهلة الممنوحة للمنشأة تقوم بتحرير محضر جنحة ويأخذ خط سيره القانونى. رابعاً: وجدنا اختلاف مابين القائمين على تطبيق القانون رقم ؟ لسنة ـ99 99 والمعدل بالقانون

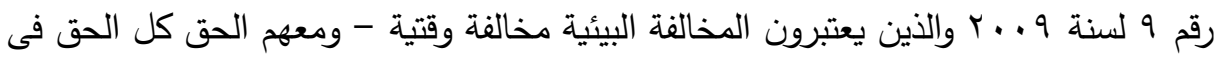

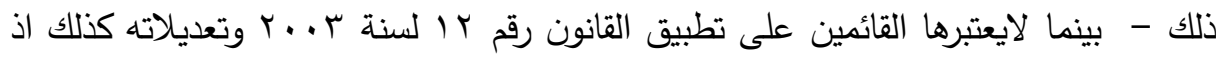

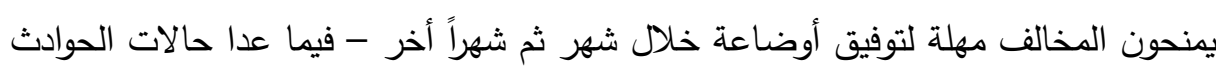
الجسيمة -ممايجعله مستهترا بالمخالفة بما لايحقق الردع الذى يهدف لـاعله له القانون. 
خامسا: وجدنا خلو التشريعات البيئية المتعددة واللوائح التتفيذية لتلك التشريعات ومنها القانون

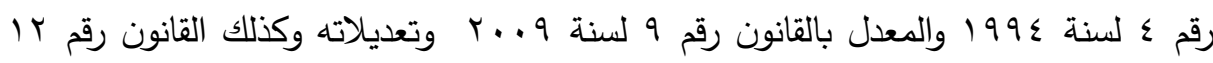

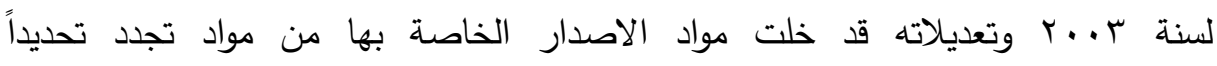

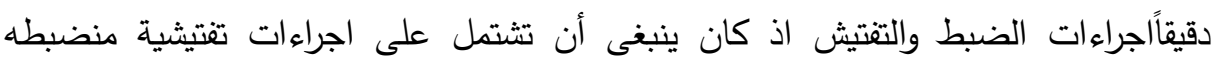

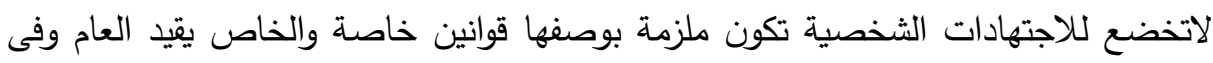

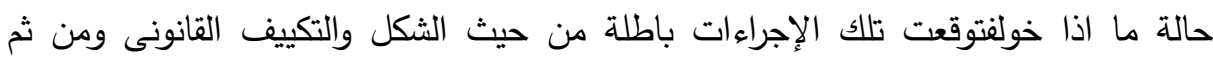

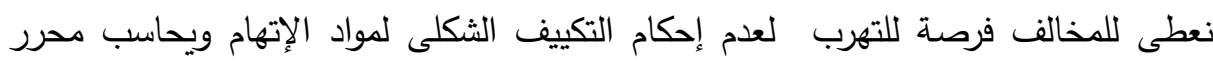

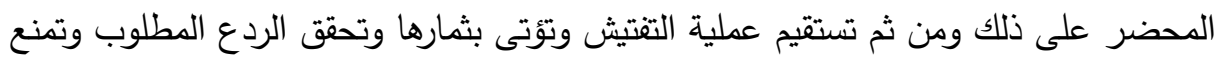

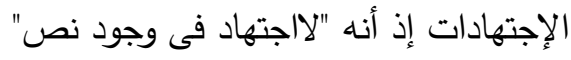

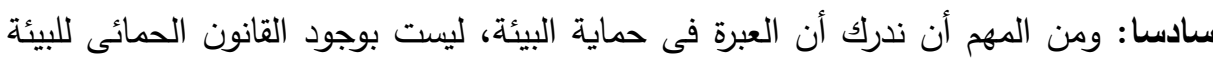

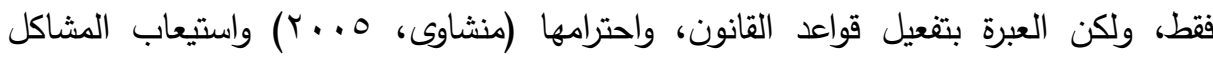

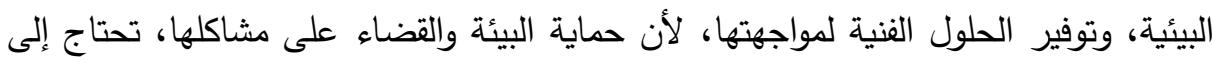
حلول فنية، بجانب قواعد قانونية جدية، وهذا يتطلب الإعتماد على الكفاءات الفنية

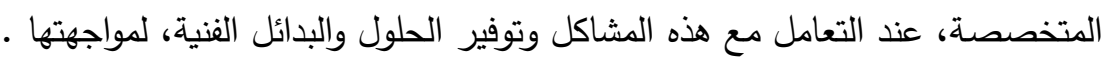
والتتظيم القانونى المقترح يجب أن يدعم الكفاءات، ويفعل العمل الجماعى الدائم لحماية البيئة، ويطبق بحزم قواعد المسئولية عن الأضرار البيئية، ويستوعب التطورات الطارئة والقاهرة، ويضع الاستعدادت القانونية لمواجهتها، وهذا يتطلب سمو قواعد حماية البيئة فوق كل القواعد، لأنها قواعد للمحافظة على الوجود الإنسانى، ويجب دعم الإنى المسئولين عن الحماية

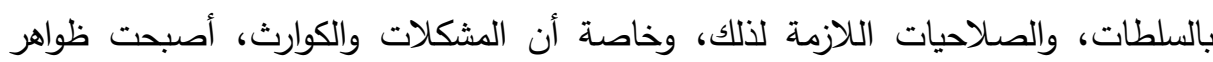

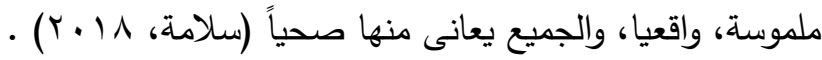

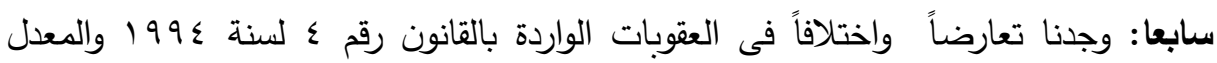

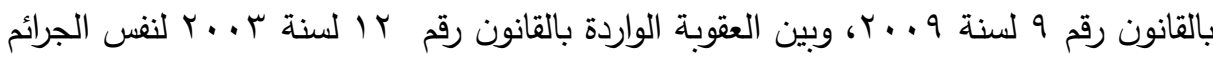

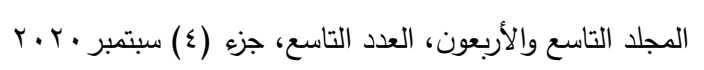

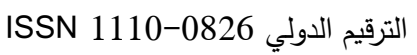


البيئية حيث ساوى القانون رقم r ا لسنة ب ... ف فى العقوبة بين جميع الجرائم البيئية الواردة

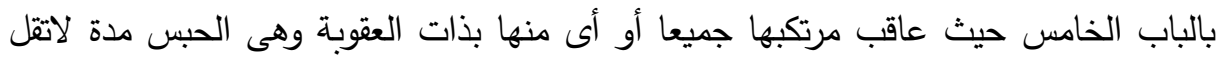
عن ثلاثة أشهر وبغرامة لاتقل عن ألف جنيها، ولاتجاوز عشرة آلاف جنيه أو بإحدى هاتين التهات العقوبتين وتكون

عقوبتا الحبس والغرامة وجوبيتين إذا ترتب على الجريمة الوفاة أو الإصابة الجسيمة، وتضاعف الغرامة فى حالة العود .

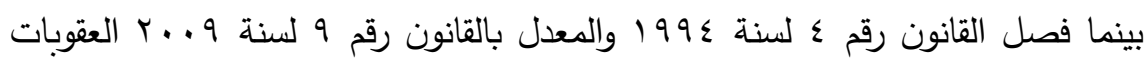
طبقاً لطبيعة كل مخالفة حيث تختلف عقوبة مرتكب مخالفة الضوضاء عن الإنبعاثات الغازية

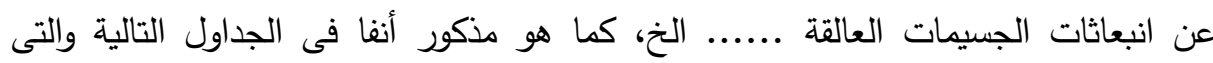

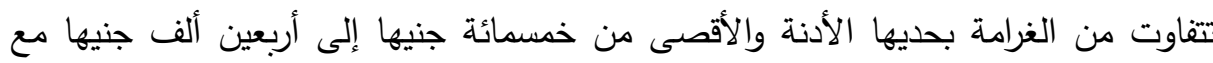

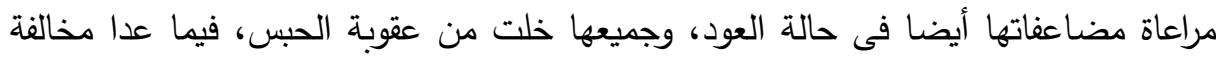
الحدود السموح بها للتلوث الإثعاعى فى الهواء فقد غُلظت فيها العقوبة إلى الحبس لمدة لاتقل فئل فئل

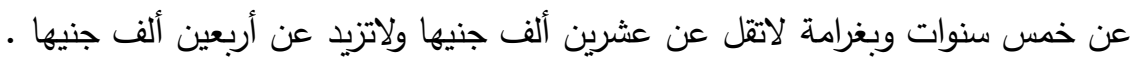

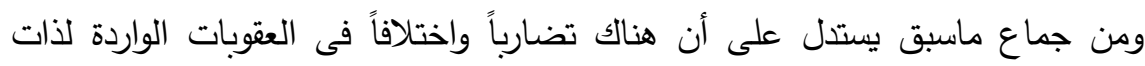

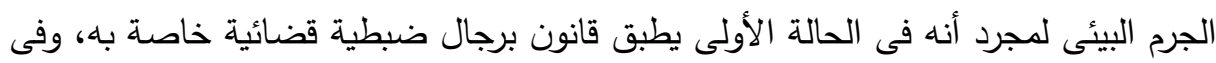

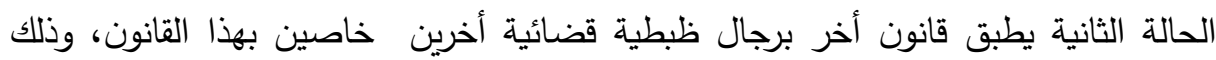
لنفس المخالفة ونفس المخالف ( المخَاطَب بتطبيق القانون عليه ) مما لاتستقيم معه العدالة لئل

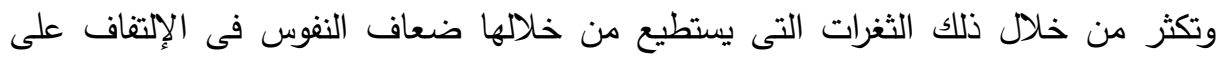
القانون، لأننا فى هذه الحالة سوف نكيل بمكيالين للعدالة لمجرد اختلاف التشريعات المتعددة

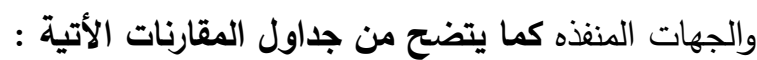

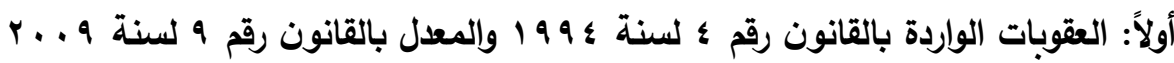


1 - أنبعاث أو تسرب ملوثات الهواء من المنشآت :

\begin{tabular}{|c|c|}
\hline مادة رقم ( • r ) - الباب الثانى ( حماية البيئة الهوائية ) & المادة \\
\hline \multicolumn{2}{|c|}{ 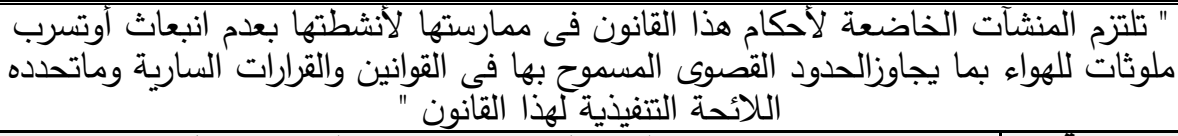 } \\
\hline مادة رقم ( Av ) - الباب الرابع ( العقوبات ) & العقوبـة \\
\hline هـ آلف & ويعافر \\
\hline
\end{tabular}

r - إستخدام الآلات و المحركات و المركبات :

\begin{tabular}{|c|c|}
\hline هب ) - الباب التانى ( حمايه البيئه (الهوائيه ) & \\
\hline 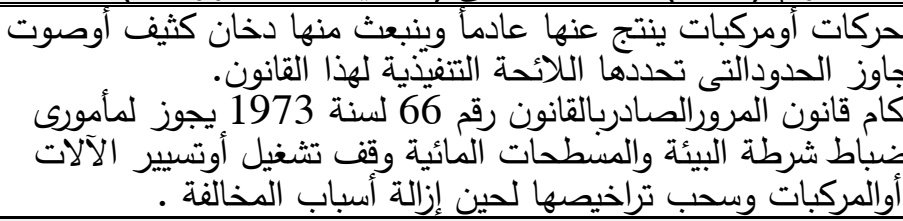 & \\
\hline مادة رقق ( 1 ) - الباب الرابع ( العقوبات ) & العقوبـة \\
\hline \multicolumn{2}{|c|}{ 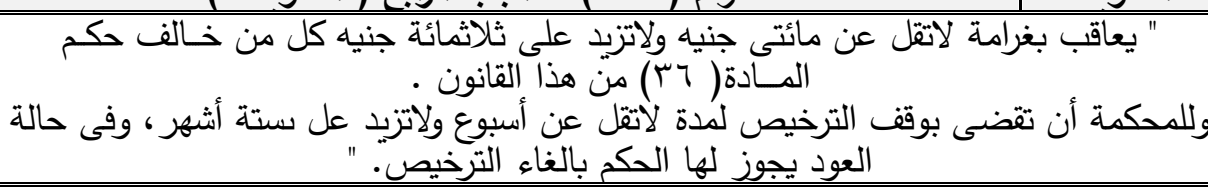 } \\
\hline
\end{tabular}

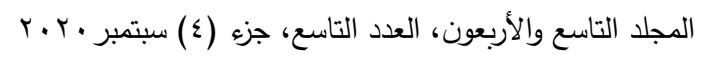

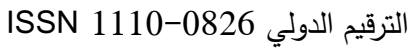


ب - مستوى الصوت

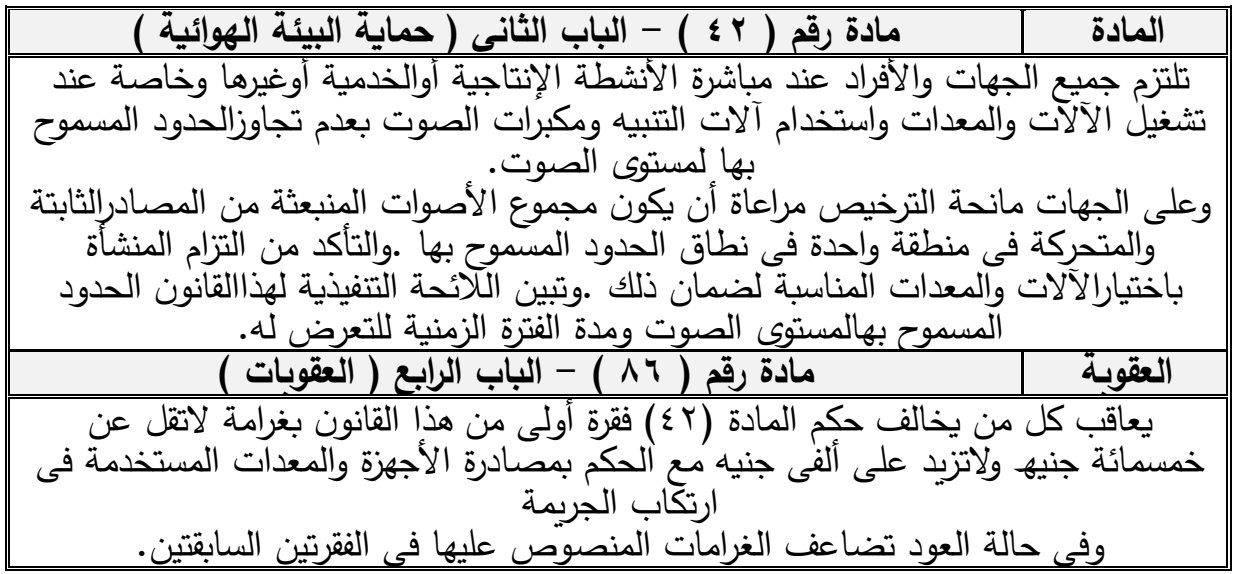

ع - ملوثات الهواء داخل أماكن العمل :

المادة

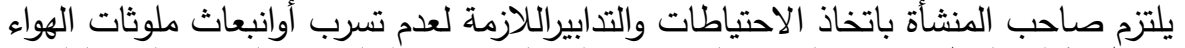

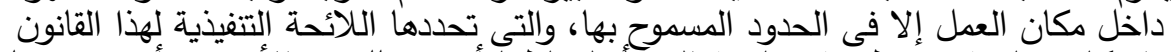

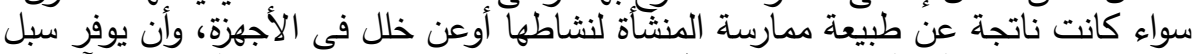

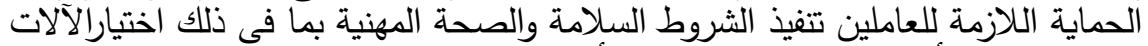

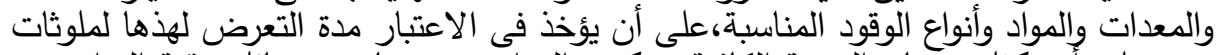

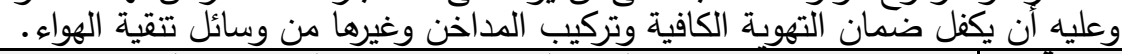
العقوبة

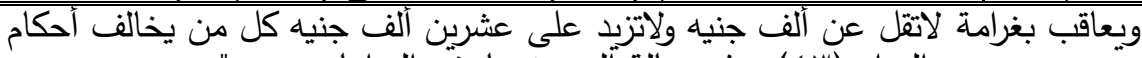

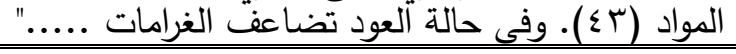


ه - درجة الحراة والرطوبة داخل أماكن العقل :

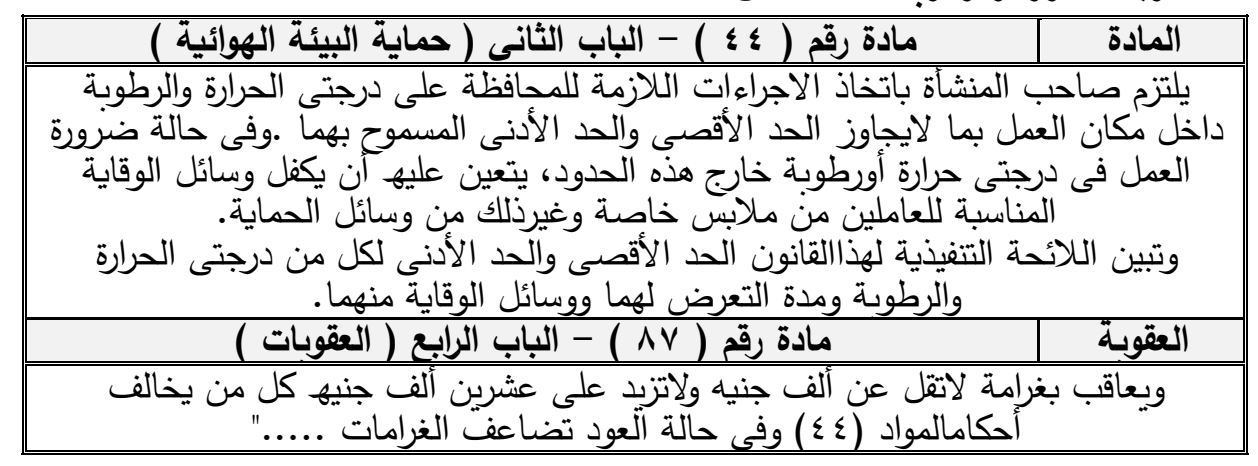

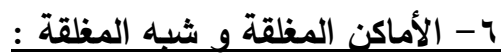

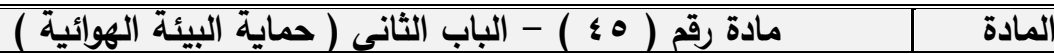

\begin{tabular}{|c|c|}
\hline مادة رقم ( 0 ؛ ) - الباب الثانى ( حماية البيئة الهوائية ) & 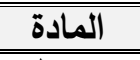 \\
\hline 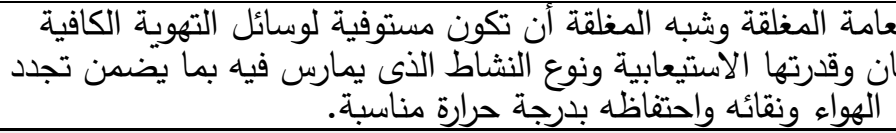 & \\
\hline مادة رقم ( AV ) - الباب الرابع ( العقوبات ) & العقوبـة \\
\hline
\end{tabular}

- V - مستوى النشاط اللأشعاعى و تركيزات المواد المشعة

\begin{tabular}{|c|c|}
\hline مادة رقم ( V ) - الباب الثانى ( حماية البيئة الهوائية ) & المادة \\
\hline لددهاط الجهات الثعاعى أوتركيزات المواد المشتعة التفيذية لهالهواء القنانون. الحدود المسموح & \\
\hline مادة رق ( A^ ) - الباب الرابع ( العقوبات ) & العقوبـة \\
\hline
\end{tabular}

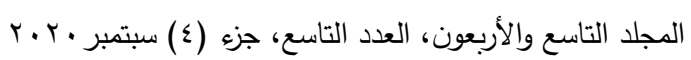

$$
\begin{aligned}
& \text { الترقيم الدولي 0826- ISSN 1110 }
\end{aligned}
$$


ثانياً : العقوبات الواردة بالقانون رقم ب ا لسنة ب . . r - الباب الخامس والسادس فى شأن

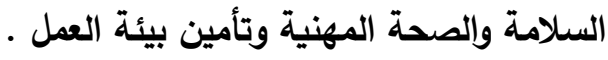

1 - تأمين بيئة العمل :

\begin{tabular}{|c|c|}
\hline مادة رقم ( > > r ) - الكتاب الخامس - الباب الثالث & المادة \\
\hline \multicolumn{2}{|c|}{ 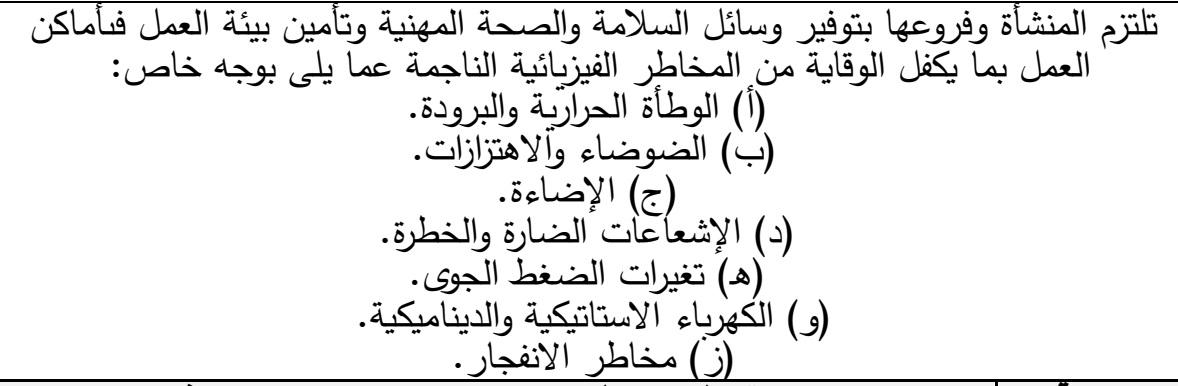 } \\
\hline مادة رقم ( †ه r ) - الكتاب السادس - الباب الثانى & العقوبـة \\
\hline 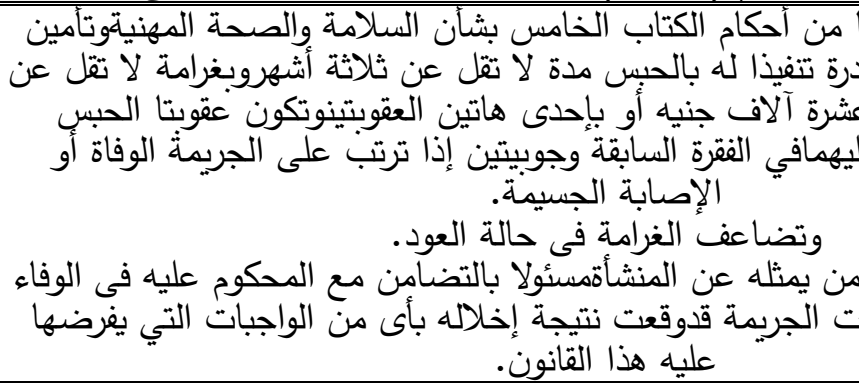 & 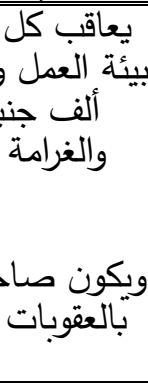 \\
\hline
\end{tabular}

\section{اللزوسيايت}

من خلال عرضنا لنتائج الرصد البيئى لملوثات الهواء بمنطقة الدراسة وكذلك دراستنا

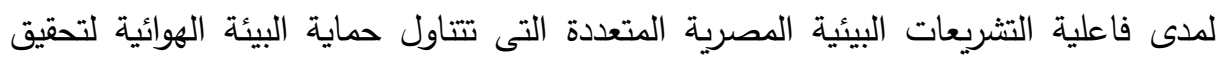

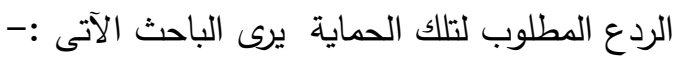


1-ضرورة عمل ميثاق موحد لحماية البيئة فى صورة إصدار قانون موحد يسمى قانون حماية البيئة الموحد وليس قانون البيئة كما يسمّى الأن، يجمع تشتت القواعد المنظمة لحمدة لحماية

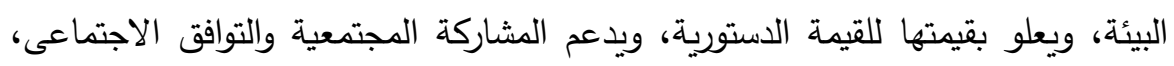

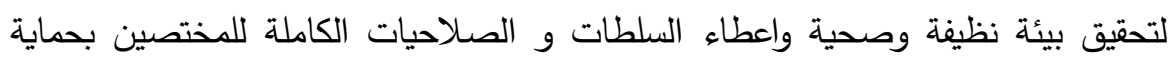
البيئة، لتفعيل الحماية على أرض الواقع، وجعل نشاط حماية البيئة نشاطا فنيا ورئيسيا

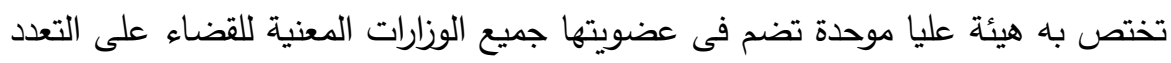
الرقابى المترتب على التعدد التشريعى، وليس نثاط ثانويا، يقتصر فقط علئه على استكمال

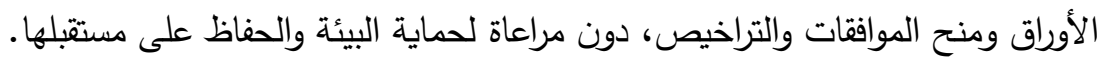

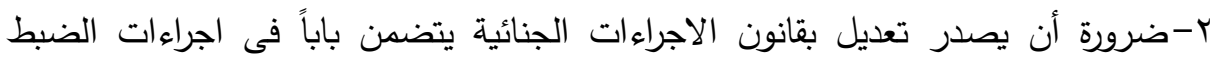

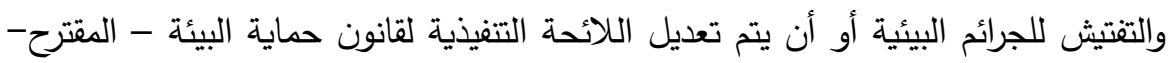
يتضمن هذا التعديل مواد صريحة توضح ضبط عمليات التقتيش البيئى والرقابة البيئية بوصفه قانون خاص والخاص يقيد العام بحيث تكون ملزمة لكلا الجانبين سواء كان مأمورى الضبطية القضائية المعنيين بالتفتيش والرقابة وانفاذ القانون أو أصحاب الأعمال

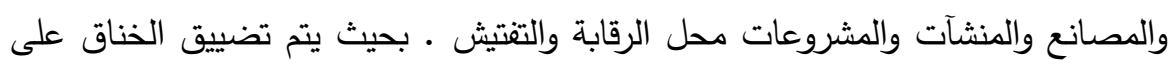

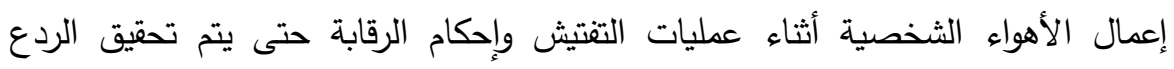

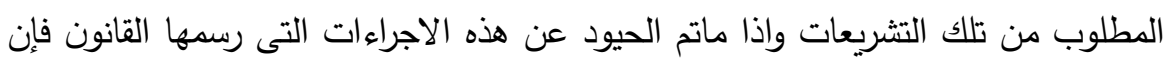
اجراءات التفتيش يثوبها البطلان ويحاسب من حاد عنها من مأمورى الضبط القضائسأسوة بقانون الإجراءات الجنائية - بوصف التعدى على البيئة جريمة بيئية تحتاج إلى حماية قانونية .

ب-ضرورة أن يأخذ قانون حماية البيئة الموحد - المقترح - بمبدأ الحوافز والجزاءات البيئية مثل مبدأ الملوث يدفع، وذلك لتجاهل كافة التشريعات البيئية المتعددة الحالية والأخذ بهذين المبدأين، مما جعل المخاطبين بتلك التشريعات يكتفون بأن القياسات البيئية

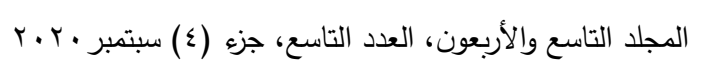

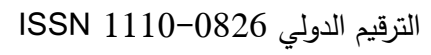


للملوثات الناتجة عن أنشطتهم المختلفة داخل الحدود المسموح بها، ولم يقدموا على اتخاذ

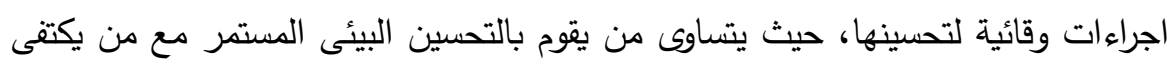

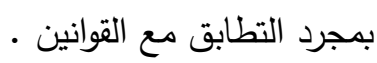

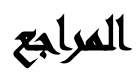

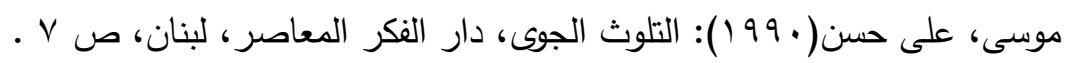
فراتش، هيلاى(ب99 ()): تلخيص الهواء من الملوثات، جدول أعمال عالمى، ترجمة أنور

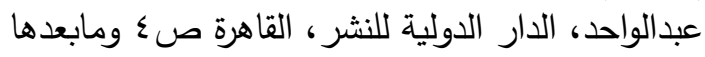

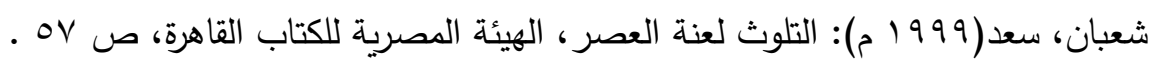

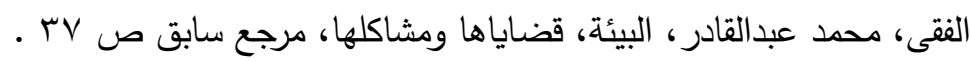
فراتش، هيلارى، تلخيص الهواء من الملوثات، مرجع سابق، ص ع ومابعدها.

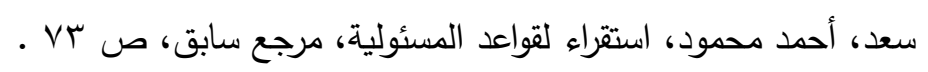

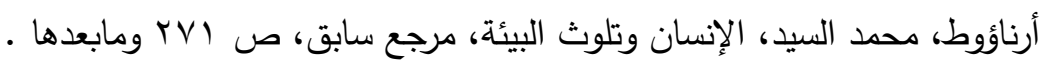

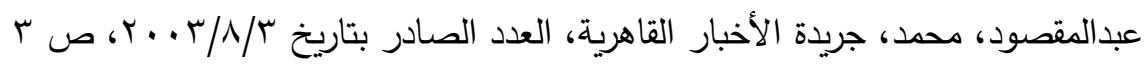

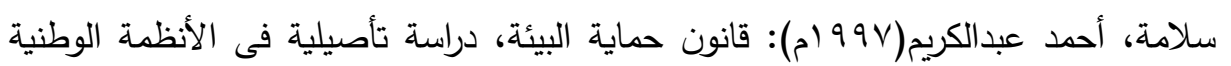

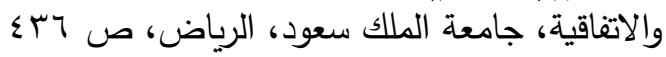

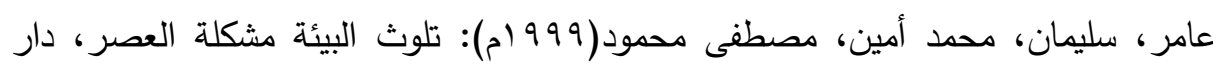
الكتاب الحديث ص 9 .

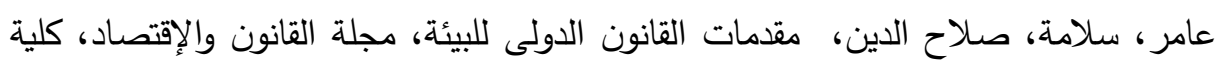

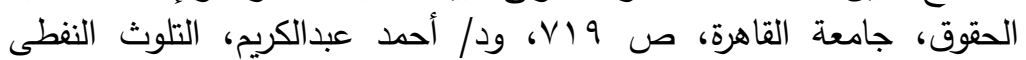

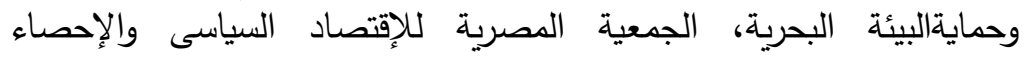

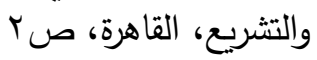

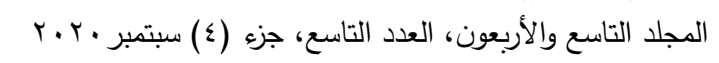

ISSN 1110-0826 الترقيم الدوني الدوني 


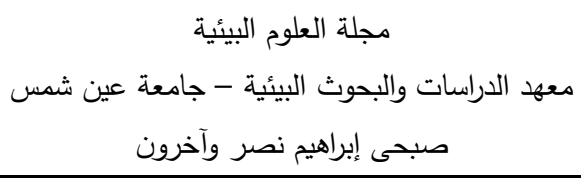

\title{
AIR QUALITY ASSESSMENT WITHIN THE \\ FRAMEWORK OF LEGISLATIVEPLURALISM FOR \\ ENVIRONMENTAL PROTECTION \\ (CASE STUDY - 10TH OF RAMADAN CITY)
}

\author{
Sobhy I. Nasr ${ }^{(1)}$; Mohamed A. Elgandy ${ }^{(2)}$; Hesham I. Elkassas ${ }^{(3)}$ \\ and Taha A. M. Abdelrazik ${ }^{(3)}$ \\ 1) post grad, Institute of Environmental Studies and Research, Ain \\ Shams University 2) Former Minister of Justice 3) Institute of \\ Environmental Studies and Research, Ain Shams University
}

\begin{abstract}
This work aims at evaluating the air quality parameters in 10th of Ramadan city in reference to Egyptian laws (9/2009, 12/2003). The main air pollution parameters were monitored all over the area of study. Results proved that total suspended particulates were not complying was the laws and raged from $62-80 \mu \mathrm{g} / \mathrm{m} 3$ in industrial areas, 55-64 $\mu \mathrm{g} / \mathrm{m} 3$ in rural areas and $54-59 \mu \mathrm{g} / \mathrm{m} 3$ in urban areas respectively compared with $50 \mu \mathrm{g} / \mathrm{m} 3$ in law $9 / 2009$. Also, carbon monoxide ranged from $22-42 \mu \mathrm{g} / \mathrm{m} 3,18-37 \mu \mathrm{g} / \mathrm{m} 3$ and $17-34 \mu \mathrm{g} / \mathrm{m} 3$ in industrial, rural areas and urban areas respectively compared with $60 \mu \mathrm{g} / \mathrm{m} 3$ in law9/2009 given that it was $50 \mu \mathrm{g} / \mathrm{m} 3$ for urban areas. In searching for such causes that leads to such situation, it was found that the cause in the light of legislation pluralism, is there are legislative conflict and many law article addressing the same item which make those whom spoke to are maneuvering from control. As an example, in chapter 6, law 12/2003 for the safety, occupational health and work environment and mentioned in law 9/2009 as well, there is difference in punishment

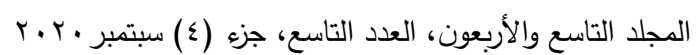

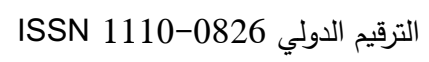




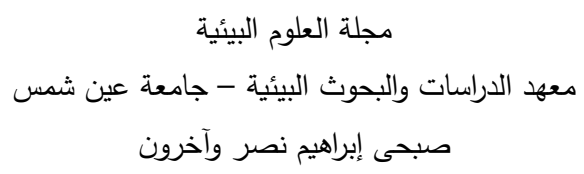

for the violation. As the first states imprisonment and fine while the second states fine only. At the same time there are no text or strict procedures regulating inspection and control in these laws. The study concluded that a unified law for controlling environment should be promulgated to collect such disseminated legislative articles and include all types of environment (water, work, ambient and industrial environments).

Key words: Air quality at 10 of Ramadan city - environmental legislative conflict - environmental legislative pluralism

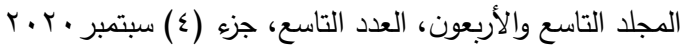

$$
\begin{aligned}
& \text { الترقيم الدولي 0826- ISSN 1110 }
\end{aligned}
$$

